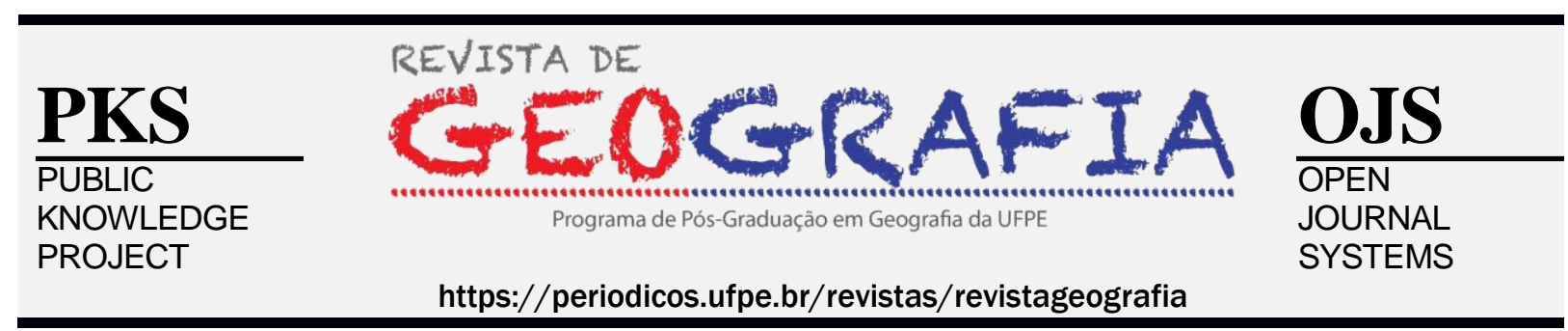

\title{
"OS VULCÕES CEARENSES" GÊNESE E EVOLUÇÃO DOS RELEVOS VULCÂNICOS DA REGIÃO METROPOLITANA DE FORTALEZA, CEARÁ
}

\author{
Anatarino Torres Costa ${ }^{1}$, Vanda Claudino-Sales ${ }^{2}$ \\ ${ }^{1}$ Geógrafo-mestre da Companhia de Gestão dos Recursos Hídricos do Estado do Ceará - COGERH. E-mail: \\ anatarino@yahoo.com.br \\ ${ }^{2}$ Professora-doutora do Mestrado Acadêmico em Geografia da Universidade Estadual Vale do Acaraú - UVA. E- \\ mail:vcs@ufc.br
}

Artigo recebido em 14/01/2019 e aceito em 11/03/2020

\begin{abstract}
RESUMO
A Região Metropolitana de Fortaleza, no Estado do Ceará, é composta por uma diversificada paisagem geomorfológica. Entre as diversas morfologias existentes, as originadas a partir do último evento vulcânico ocorrido no Nordeste brasileiro há 30 milhões de anos merecem destaque devido sua singularidade. São formados por uma dezena de pequenos relevos, dentre eles os montes Caruru, Ancuri e Pão-de-Açúcar. Esta pesquisa tem como objetivo estabelecer a origem, estruturação e caracterização morfológica destes relevos, assim como definir as etapas da evolução geomorfológica da paisagem local. Para compreender tais objetivos foram realizadas pesquisas bibliográficas, em particular sobre vulcanismo, interpretação de material cartográfico de diversas escalas, produção de dados físicos-ambientais com apoio de ferramentas de geoprocessamento e visitas a campo. Como resultados pode-se concluir que os relevos da Formação Messejana se apresentam em formas de necks arredondados (Caruru e Pão-de-Açúcar) e elipsoidal (Ancuri) e são compostos por rochas alcalinas. Tais relevos se caracterizam por apresentarem extensões e altitudes bem diferentes, vertentes íngremes, solos poucos desenvolvidos e vegetação de pequeno porte. Os relevos vulcânicos servem como balizador geomorfológico da deposição da Formação Barreiras. Alguns dentre esses relevos estão sujeitos à mineração e apresentam-se relativamente descaracterizados. $\mathrm{Na}$ totalidade, nenhum dos resquícios dos vulcões extintos da Região Metropolitana de Fortaleza conta com qualquer tipo de proteção ambiental.
\end{abstract}

Palavras-chave: Vulcanismo Terciário no Nordeste, Relevos vulcânicos, Formação Messejana, vulcões do Ceará. 


\title{
"THE VOLCANOES OF CEARÁ STATE" GENESIS AND EVOLUTION OF THE VOLCANIC FEATURES OF THE METROPOLITAN REGION OF FORTALEZA, CEARÁ
}

\begin{abstract}
The Metropolitan Region of Fortaleza, in the State of Ceará, is composed of a diverse geomorphological landscape. Among the different morphologies, the forms originated from the last volcanic event occurred in the Brazilian Northeast around 30 million years ago are special, due to their singularity. They are formed by ten small features, among them the mounts Caruru, Ancuri and Sugarloaf. This research aims to establish the origin, structure and morphological characterization of these reliefs, as well as to define the stages of the geomorphological evolution of the local landscape. In order to understand these objectives, we sought to deepen the bibliography on volcanism, interpretation of cartographic material from different scales, physical-environmental data with the support of geoprocessing tools and field visits. As results, we can conclude that the three volcanic features of the Messejana Formation analyzed in this work form rounded (Caruru and Pão-de-Açúcar) and ellipsoidal (Ancuri) necks and are composed of alkaline rocks. Very different extensions and altitudes, steep slopes, few developed soils and scarce vegetation characterize them. The volcanic reliefs serve as a geomorphological marker for the deposition of the Barreiras Formation. Some of these features were subject to mining and are relatively decharacterized. In total, none of the extinct volcanoes of the Metropolitan Region of Fortaleza has any type of environmental protection. Keywords: Tertiary volcanism in Brazilian Northeast, volcanic landforms, Messejana Formation, Ceará volcanoes.
\end{abstract}

\section{INTRODUÇÃO}

O Estado do Ceará, Nordeste do Brasil, compreende uma área de aproximadamente 147 mil $\mathrm{Km}^{2}$, apresentando um quadro geomorfológico com grande diversidade de paisagens, as quais se estruturaram ao longo do tempo devido a movimentos tectônicos, mudanças climáticas, denudação generalizada, variações do nível do mar e, mais recentemente, também em função de fatores associados com uso e ocupação do solo.

Alguns eventos morfotectônicos do Ceará são de escala local, enquanto outros são de escala regional. Como exemplo de fenômenos de dimensão regional na paisagem local, cita-se os relevos oriundos de processos vulcânicos.

O fenômeno vulcanismo é o resultado da ascensão do magma à superfície terrestre (e.g. SZABÓ et al, 2007). O material originado por esse processo (a lava), de maneira geral, se apresenta de três formas (gasosa, líquida e sólida), e suas características dependerão essencialmente da composição original do magma, bem como das condições de temperatura e pressão (e.g. FRANCIS e OPPENHEIRM, 2003). Apesar dos avanços tecnológicos, coloca-se que o vulcanismo, dentre todos os fenômenos naturais, é um dos mais complexos e desconhecidos no tocante aos mecanismos de gênese e evolução.

No Brasil atualmente não ocorre esse tipo de processo, pois as atividades sísmicas e vulcânicas do nosso planeta estão concentradas ao longo dos limites de placas tectônicas (e.g. TEIXEIRA, 2007). Geologicamente, o Brasil está localizado no centro de uma grande placa 
tectônica, a placa Sul-americana, portanto, afastado dos limites ativos (BRITO NEVES e SCHOBBENHAUS, 2003). Porém, nem sempre foi assim. Em períodos anteriores da história geológica, importantes eventos magmáticos ocorreram de forma intensa em várias regiões brasileiras. Braun (2005) relata que episódios vulcânicos estão bem representados no escudo brasileiro desde o Arqueano até o Cenozoico, sendo a sequência de episódios mais bem estudada, a de idade meso-cenozoica.

Uma das regiões influenciadas por eventos desse tipo durante a era Mesozoica foi a do Nordeste Brasileiro, que passou por tais processos notadamente na sua porção oriental. As atividades magmáticas ocorreram do Jurássico inferior (203-175 Ma) ao Cretáceo inferior (13596 Ma) (MARTINS e OLIVEIRA, 1992). Posteriormente, ocorreram deformações tectônicas cretáceas que resultaram na abertura dos continentes africano e sul-americano e na formação da margem continental do nordeste brasileiro, com geração e evolução do assoalho oceânico (MATOS, 2000). Essas manifestações se deram através de fenômenos magmáticos intrusivos e efusivos, os quais originaram diversos tipos litológicos (ALMEIDA et al., 1996).

Na sequência da evolução termotectônica da margem continental do Nordeste, registrase que por volta de 30 milhões de anos, na época Oligoceno do período Terciário, ocorreram pequenas atividades vulcânicas em setores continentais dos estados do Rio Grande do Norte, Ceará e Paraíba (ALMEIDA et al., 1988).

No Ceará, as fácies vulcânicas originadas nesse período receberam a denominação geológica de Formação Messejana. Sua primeira referência data da década de 1950, feita pelo geólogo e pesquisador Fernando Flávio Marques de Almeida, que associou relevos da ilha de Fernando de Noronha a essa formação e a definiu como fazendo parte da zona de fraturas da cadeia vulcânica desse arquipélago (ALMEIDA, 1955).

Apesar de estarem expostas aos ataques dos agentes modeladores externos pelo intervalo de tempo de 30 milhões de anos, as fácies vulcânicas relativas à Formação Messejana ainda persistem na paisagem natural de alguns dos municípios da Região Metropolitana de Fortaleza (Figura 1), na forma de dez feições de relevo de pequena envergadura. Eles representam um elemento geomorfológico peculiar, compondo a forma mais heterogênea da paisagem local. Os relevos e estruturas vulcânicas da RMF são pouco detalhados pelos levantamentos geológicos existentes, e carecem de qualquer tipo de levantamento geomorfológico. A pesquisa da qual resultou o presente artigo é pioneira nesse sentido. 


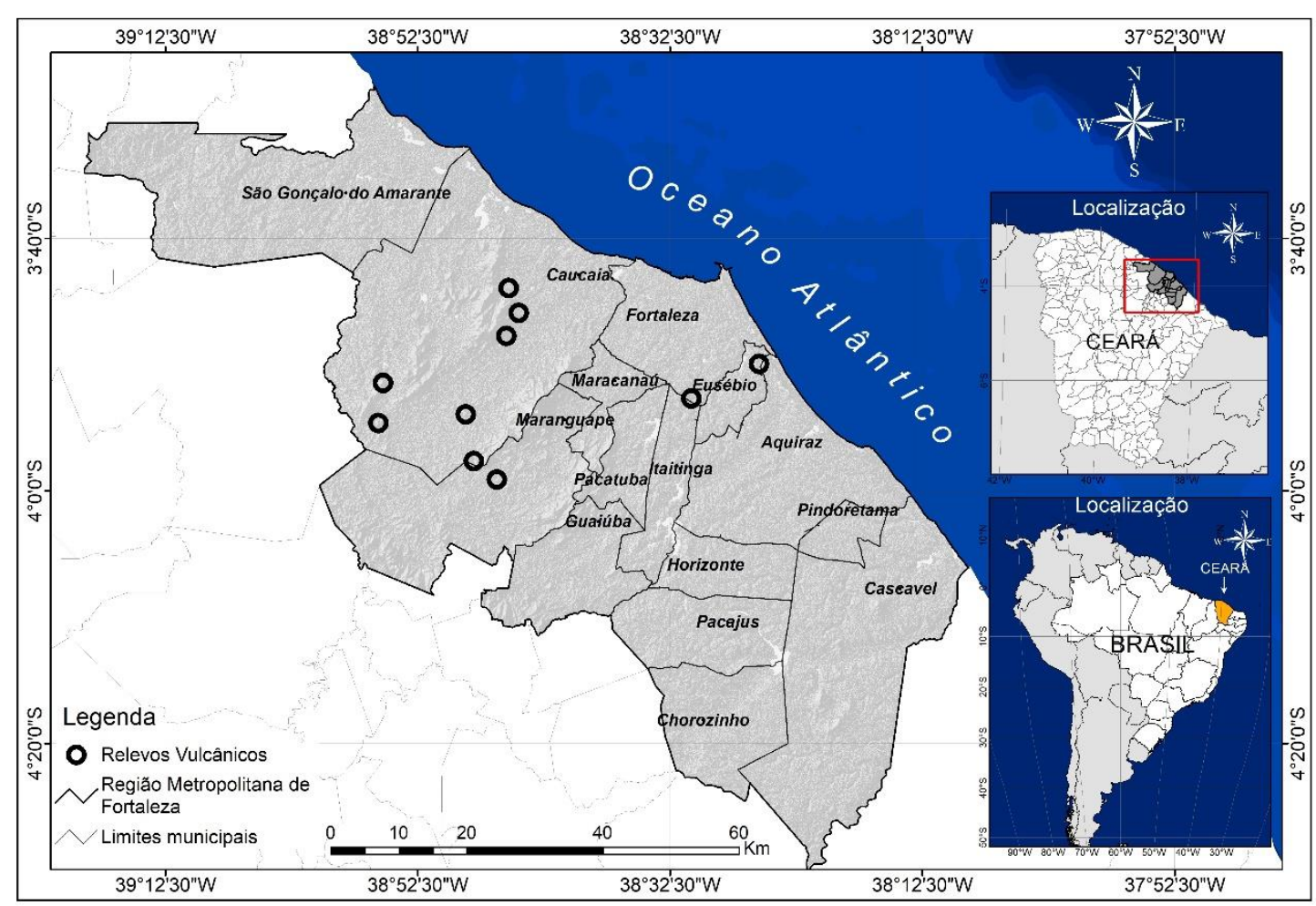

Figura 1. Localização dos relevos vulcânicos da Região Metropolitana de Fortaleza

\section{CARACTERIZAÇÃO GEOAMBIENTAL DA REGIÃO METROPOLITANA DE FORTALEZA}

A Região Metropolitana de Fortaleza apresenta na sua porção central rochas de natureza granitóide-migmatítica de idade arqueana- proterozóica. Na porção centro-oeste e extremo leste ocorrem rochas gnáissicas e migmatíticas de idade proterozoica. Distribuindo-se como uma faixa de largura variável acompanhando a linha de costa a retaguarda de sedimentos eólicos cenozoicos da planície litorânea, ocorre a Formação Barreiras, depósito sedimentar de idade terciária. Sobressaindo-se sobre a Formação Barreiras e sobretudo sobre o embasamento cristalino, ocorrem as estruturas vulcânicas da Formação Messejana, de idade terciária, composta por fonólitos, traquitos e tufos vulcânicos (CPRM, 2014; BRANDÃO, 1995) (Figura 2). 


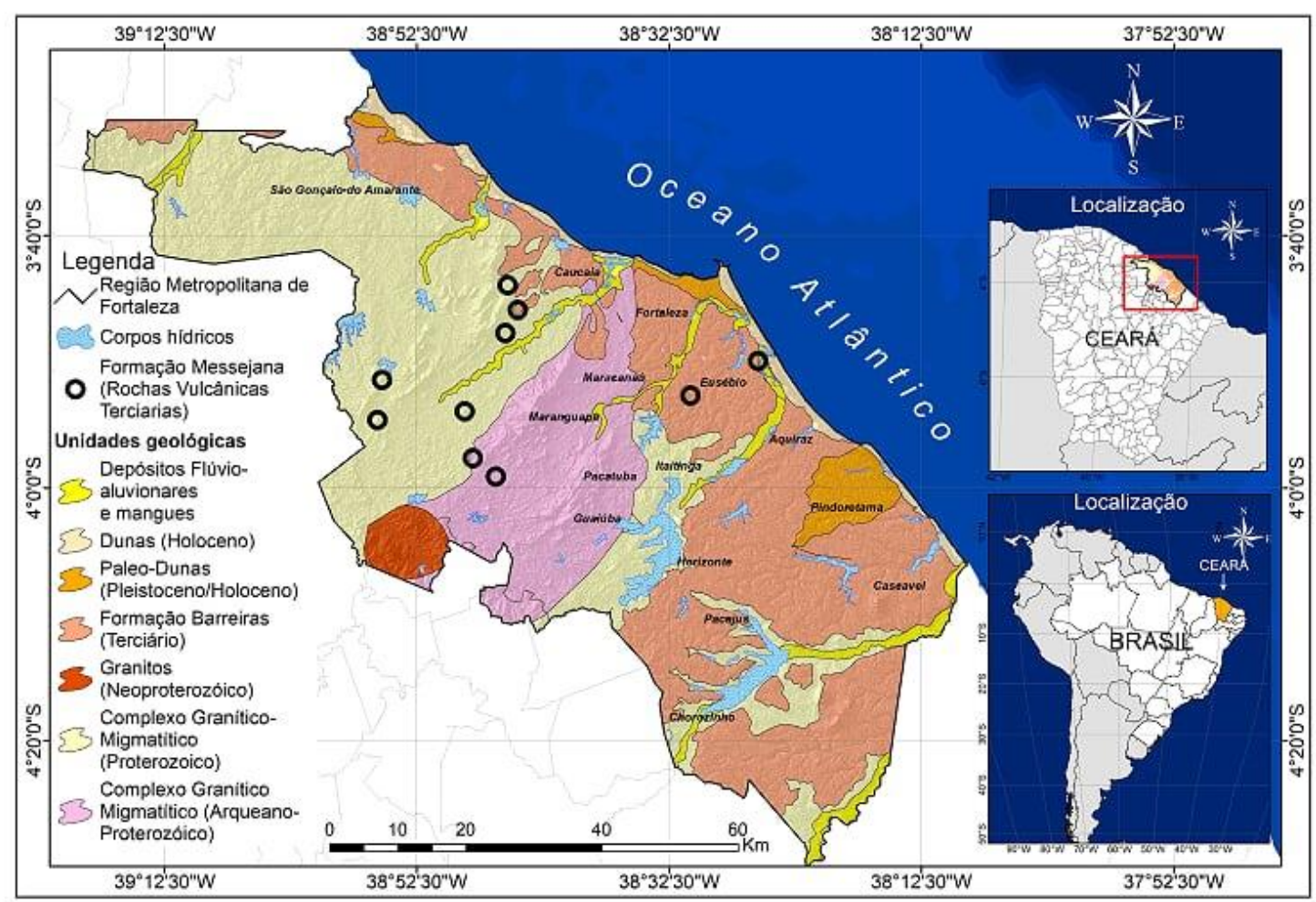

Figura 2. Geologia da Região Metropolitana de Fortaleza (adaptado de Projeto SINFOR-CPRM, 1995).

Quanto aos aspectos do relevo da RMF, as altitudes variam de 0 a $800 \mathrm{~m}$, com predomínio de altitudes abaixo de 100m (SEMACE, 2006; BÉTARD et al., 2007). Ocorrem cinco domínios geomorfológicos: (1) planície litorânea, composta por dunas e praias formadas por areias quaternárias; (2) tabuleiros costeiros, que caracterizam relevos planos sustentados pela Formação Barreiras; (3) superfície sertaneja, que representa um pediplano elaborado no embasamento cristalino pré-cambriano; (4) maciços residuais, modelados em rochas do embasamento cristalino, em particular onde ocorrem litologias mais resistentes como quartzitos, granitos e migmatitos, representando as maiores altitudes e ocorrendo de forma dispersa em alguns municípios que compõem a região metropolitana; (5) vales fluviais, com planícies fluviais aluvionares e planícies flúvio-marinhas (Figura 3).

Sobressaindo-se na superfície sertaneja e nos tabuleiros costeiros, em alguns casos, ocorrem as feições elaboradas nas estruturas vulcânicas da Formação Messejana. Essas estruturas se destacam na paisagem majoritariamente rebaixada da grande Fortaleza, na forma de feições de relevo de pequena envergadura, na sua grande maioria representando serrotes de variados tamanhos e cristas de pequeno porte. 
A RMF apresenta tipo climático Aw da classificação de Köppen (ÁLVARES et al., 2013), pertencente ao grupo de clima tropical chuvoso, onde a época mais seca ocorre no inverno e o máximo das chuvas ocorre no outono (ZANELA, 2005). O maior município da RMF, Fortaleza, banhado pelo Oceano Atlântico, apresenta média de precipitação da ordem de 1620 mm (FUNCEME, 2018), atingindo o valor máximo entre março e abril, em função da penetração nesses meses da Zona de Convergência Intertropical - ZCIT (ZANELA, 2005). Na RMF, a precipitação média anual encontra-se entre 900 e 1600 mm (FUNCEME, 2018), ocorrendo núcleos diferenciados de chuvas orográficas nos maciços cristalinos (Serras da Pacatuba, Aratanha e Maranguape) (SABADIA e CASAS, 2003).

No tocante à temperatura, Fortaleza apresenta uma média anual de $26,5^{\circ} \mathrm{C}$. As médias das máximas ficam em torno de $29,7^{\circ} \mathrm{C}$ e a das mínimas $23^{\circ} \mathrm{C}$. Os principais fatores de atenuação da temperatura são decorrentes da ação da ZCIT e da ação dos ventos alísios de SE e NE, além das brisas marítimas (ZANELA, 2005; FUNCEME, 2018).

Quanto aos solos, na planície litorânea ocorrem neossolos quartzarênicos. Os tabuleiros costeiros são caracterizados pela presença de argissolos vermelho-amarelo distróficos. Na superfície sertaneja e nos maciços cristalinos predominam os argissolos vermelho-amarelos eutróficos. Nos vales fluviais ocorrem neossolos flúvicos nas planícies fluviais, e gleissolos sálicos nas planícies flúvio-marinhas (SANTOS e SOUZA, 2007).

Os componentes florísticos da área analisada são: vegetação pioneira psamófila e subperenifólia nos ambientes de pós-praia e dunas; vegetação perenifólia de mangue, encontradas nas planícies flúvio-marinhas; vegetação de várzea, presente nas planícies fluviais; vegetação dos tabuleiros litorâneos (mata de tabuleiro), que apresenta uma grande diversificação vegetacional e florística com espécies do cerrado e das dunas fixas e da caatinga, e finalmente, vegetação da caatinga, do tipo mata seca na superfície sertaneja e mata úmida nos maciços cristalinos (SEMACE, 2006). 


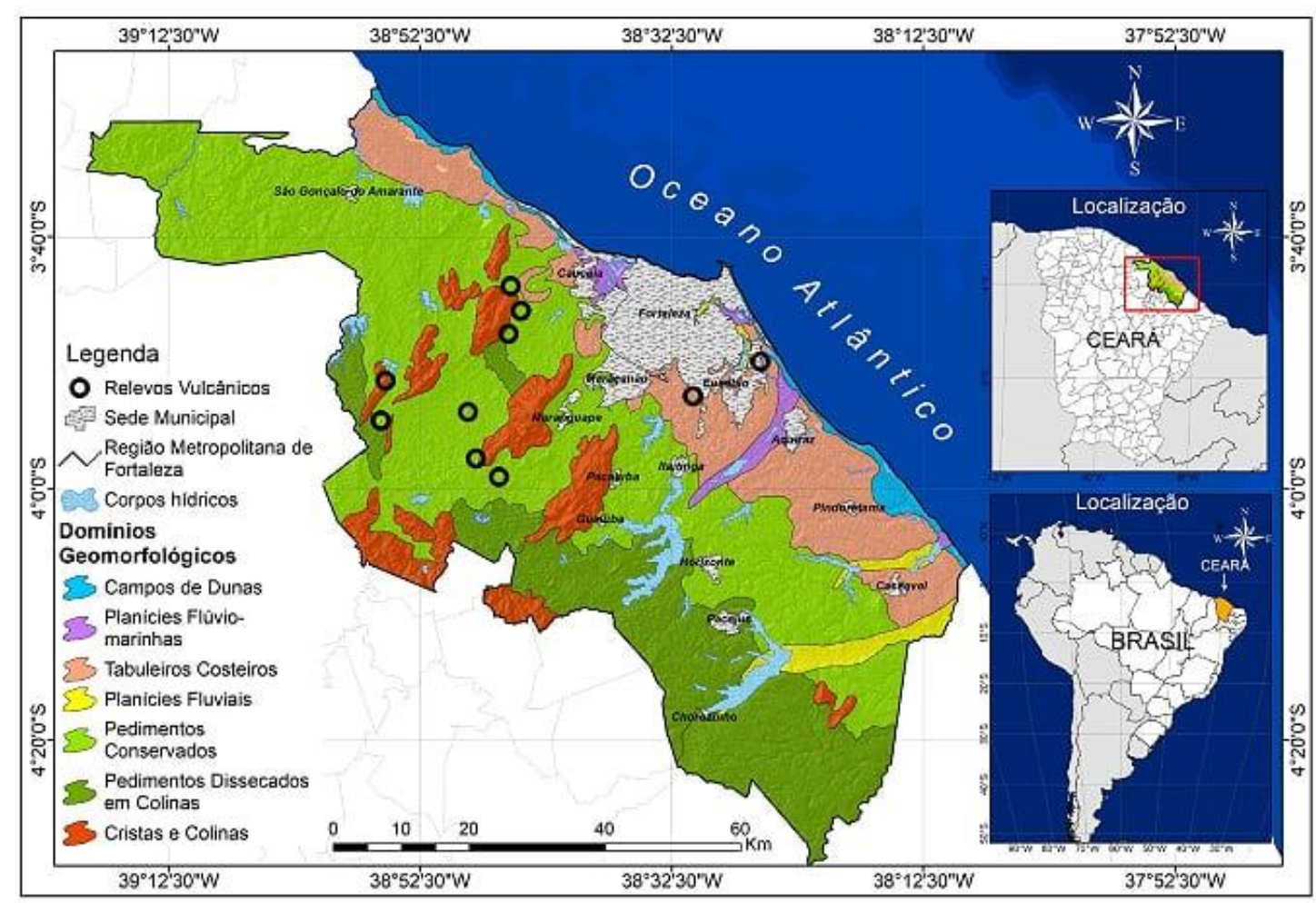

Figura 3. Esboço geomorfológico da Região Metropolitana de Fortaleza (Adaptado e atualizado a partir de "Projeto SINFOR-CPRM", 1995).

Quanto às águas superficiais, três bacias se destacam na Região Metropolitana de Fortaleza: a parte norte está representada pela bacia hidrográfica do Rio Cocó e seus afluentes, que são os riachos Gavião, Pacatuba, Serrinha, Alegrete e Coaçu (CLAUDINO-SALES, 1993). O Rio Cocó é o recurso hídrico de maior porte da área de estudo, e deságua no segmento leste de Fortaleza. A porção sul pertence à bacia hidrográfica do Rio Pacotí, que serve como base para o sistema Pacotí-Riachão-Gavião, fundamental no processo de abastecimento de Fortaleza. O Rio Pacoti também deságua a leste, com desembocadura distando cerca de $7 \mathrm{~km}$ daquela do Rio Cocó. A leste, ocorre a bacia hidrográfica do Rio Ceará, com desembocadura no extremo leste do município de Fortaleza (COGERH, 2018).

As fraturas herdadas do vulcanismo terciário apresentam direção NE, sendo importantes guias na hidrogeologia da Região Metropolitana de Fortaleza em dois aspectos: o primeiro refere-se ao condicionamento de circulação da água obedecendo ao trend geral dos principais lineamentos estruturais da região; e o segundo, diz respeito à presença de aquíferos de boa 
qualidade e com boas vazões dentro desses condutos estruturais (MOTA, 2005; COSTA, 2008; CLAUDINO-SALES e LIRA, 2011).

Salienta-se que todos os domínios naturais da RMF se apresentam extremamente alterados e degradados, em função da intensa urbanização que caracteriza a região, a qual se fez ao longo das décadas sem compromisso com a manutenção da integridade dos seus atributos naturais. A vegetação, as dunas e as planícies fluviais são sem dúvida os elementos naturais mais descaracterizados na área de pesquisa.

Em relação aos relevos vulcânicos, alguns dentre eles são ou foram objeto de mineração, por vezes, bastante intensa, ao ponto de colocá-los sob o risco de desaparecimento completo na paisagem da RMF. Na atualidade, as atividades de mineração praticamente cessaram na maioria das feições vulcânicas, mas não existe nenhuma garantia de que não voltem a ocorrer em futuro próximo, pois os relevos vulcânicos encontram-se situados em propriedades privadas e não contam com nenhum tipo de proteção ambiental.

\section{METODOLOGIA}

Para a realização dessa pesquisa, utilizou-se a análise morfoestrutural, pautada no "Princípio do Uniformitarismo". O Princípio do Uniformitarismo, definido pela expressão "o presente é a chave do passado", foi apresentado na Inglaterra por James Hutton no século XVIII, e posteriormente atualizado para "Princípio do Atualismo", no sentido de considerar que os processos que atuam na Terra se repetem ao longo da história geológica, ainda que não necessariamente com a mesma intensidade na escala temporal (CARNEIRO et al.,1994). Tal fato enseja a compreensão da evolução dos relevos em longo prazo. A partir dessa perspectiva, é possível recompor a história evolutiva das paisagens naturais (CLAUDINO-SALES, 2016).

Convém ressaltar que o Uniformitarismo é um método de pensamento e não uma generalização empírica (SALGADO-LABOURIAU, 1998), sendo bastante aceito nas pesquisas mundiais em geociências. (CARNEIRO et al., 1994).

A partir da análise morfoestrutrual pautada no Uniformitarismo, verificou-se a intervenção pretérita dos agentes geomórficos nos relevos vulcânicos, definiu-se as etapas da ação vulcânica regional (processos específicos e associações com a geodinâmica), da evolução geomorfológica (taxas de erosão e evolução sedimentar das áreas do entorno dos relevos) e morfometria dos relevos vulcânicos da Formação Messejana, visando esclarecer os eventos responsáveis pela gênese e evolução dessas feições, nos seguintes termos: 
(1) A análise morfoestrutural baseia-se na interpretação de dados resultantes da superposição (em ambiente SIG) de mapas geológicos e geomorfológicos, para definir existência de zonas de cisalhamento, fraturamentos, lineamentos e tipologia litológica com a ocorrência de importantes volumes de relevo e fenômenos geomorfológicos como vertentes, pedimentos, cones de dejeção. Foram ainda realizados perfis topogeológicos, para analisar espacialmente a interdependência dos fatores detectados na superposição de mapeamentos.

(2) As etapas da ação vulcânica regional (processos específicos e associações com a geodinâmica) foram definidas a partir de pesquisa bibliográfica, sobre vulcanismo em geral e sobre o vulcanismo em análise na área de pesquisa, associando esses dados com os obtidos na etapa de superposição de mapeamentos.

(3) A evolução geomorfológica (taxas de erosão e evolução sedimentar das áreas do entorno dos relevos) e morfometria dos relevos vulcânicos foram calculadas pelos dados obtidos na pesquisa in situ e através da análise de mapas e perfis topogeológicos.

Do ponto de vista das técnicas, a pesquisa foi realizada em três etapas: gabinete, laboratório e campo. Na etapa de gabinete, foi realizada pesquisa bibliográfica aprofundada, particularmente sob os aspectos geológicos associados com vulcanismo e evolução da Formação Barreiras.

A etapa de laboratório envolveu geoprocessamento, durante o qual material cartográfico foi analisado minuciosamente em diversas escalas e datas, permitindo a caracterização e mapeamento das áreas do setor de estudo. O geoprocessamento deu-se através do uso dos programas Macrostation, com imagens do Google Earth, Global Mapper e SRTM (Shuttle Radar Topographic Mission) (produção de perfis e visão em 3D da área ao entorno dos relevos vulcânicos), Google Maps, Yahoo Maps e desenhos esquemáticos em ferramentas de desenho como o paint.

Finalmente, foram realizados sucessivos trabalhos de campo, na perspectiva de realizar reconhecimento e detalhamento dos aspectos geomorfológicos principais dos relevos vulcânicos da região Metropolitana de Fortaleza, objetivando desvendar os processos evolutivos dessas formas e a sua caracterização geoambiental. Os trabalhos de campo foram realizados em todas as etapas da pesquisa. 


\section{CARACTERIZAÇÃO DOS RELEVOS VULCÂNICOS DA REGIÃo METROPOLITANA DE FORTALEZA: OS VULCÕES DO CEARÁ}

Os corpos vulcânicos pertencentes à Formação Messejana encontram-se distribuídos em forma de arco ao redor da cidade de Fortaleza, em alguns dos municípios de sua região metropolitana, como Fortaleza, Eusébio, Maranguape e Caucaia (Figura 1).

A disposição em arco dos relevos vulcânicos, correspondendo à extensão da área de extrusão do magma em direção ao interior do continente, eventualmente pode ter sido controlada pela ocorrência de litosfera mais espessa no setor do maciço de Baturité, situado a sul da RMF, e suas vertentes costeiras (Serras da Aratanha e Maranguape), situadas na RMF. Essa maior espessura da litosfera foi constatada em pesquisas geológicas sobre esse segmento do Ceará (CARNEIRO et al., 1989), e pode ser efetivamente um fator condicionante da disposição em arco dos relevos vulcânicos na região.

Quanto à estrutura, os relevos sustentados pelas rochas da Formação Messejana são formados por necks e diques. Os necks representam estrutura na forma de cone truncado, originadas pela solidificação de magma dentro do cone de um vulcão ativo. Na sequência evolutiva, o edifício vulcânico passa por erosão e é destruído, restando apenas lava consolidada no seu interior (o neck) (FRANCIS e OPPENHEIRM, 2003; WINGE, 2014). Os diques representam injeção de magma em rochas pré-existentes. O magma penetra através de falhas e fissuras, criando estruturas normalmente tabulares no interior das rochas encaixantes (LEINZ e AMARAL, 1987; WINGE, 2014).

\section{Petrologia dos vulcões}

Desde sua primeira citação em trabalhos científicos (ALMEIDA, 1955), e em trabalhos posteriores, as características petrográficas da Formação Messejana têm sido sempre associadas com as rochas do Arquipélago de Fernando de Noronha, devido, especialmente, ao seu conteúdo alcalino.

A variedade composicional das rochas ígneas é consequência natural da variedade composicional dos magmas a partir dos quais se consolidaram. A origem dos magmas alcalinos é atribuída a pequenas frações de fusão parcial em níveis relativamente profundos do manto (FRANCIS e OPPENHEIRM, 2003). Suas características dependem do grau de fusão parcial, pressão, $\mathrm{H}_{2} \mathrm{O}, \mathrm{CO}_{2}$ e voláteis. O caráter alcalino aumenta com a profundidade no manto e com a menor quantidade de fusão parcial (e.g. BOILLOT, 1990). 
Granitos e basaltos são as rochas ígneas mais representativas da crosta terrestre. Elas podem ser, de acordo com composição química, ácidas, com teor de sílica superior a 66\%, intermediárias, com teor de sílica entre 66 e 52\%, básicas, com teor de sílica entre 52 e $45 \%$ e ultrabásicas, quando o teor de sílica é inferior a 45\%. (SZABÓ et al., 2007).

Segundo os mesmos autores, em rochas ácidas e intermediárias, predominam amplamente os minerais félsicos, de cores claras, e com alto teor de $\mathrm{Si}, \mathrm{Al}$, $\mathrm{Na}$ e $\mathrm{K}$, representados principalmente pelos feldspatos e fedspatóides, além do próprio quartzo. Quanto à relação composicional entre sílica $\left(\mathrm{Sio}_{2}\right)$ e alumina $\left(\mathrm{Al}_{2} \mathrm{O}_{3}\right)$, e ao conteúdo em álcalis $\left(\mathrm{Na}_{2} \mathrm{O}\right.$ e $\left.\mathrm{K}_{2} \mathrm{O}\right)$, as rochas muito ricas em álcalis apresentam composição mineralógicas peculiares, com minerais máficos de $\mathrm{Na}$ e K, e são denominadas rochas alcalinas; quando possuem fedspatóides, são também chamadas de rochas insaturadas (baixa quantidade) em sílica (TEIXEIRA, 2007; FRANCIS e OPPENHEIRM, 2003). Portanto, rocha alcalina é qualquer rocha que apresente álcalis em excesso na sua composição. Quando a quantidade de álcalis é superior àquela que seria acomodada em feldspatos, o excesso aparece na moda como feldspatóide, piroxênio e anfibólio sódicos e outras fases ricas em álcalis (LEINZ e AMARAL, 1987; DANA, 1984).

De acordo com Braga et al. (1981), estudos petrográficos revelaram quatro tipos alcalinos entre as variedades texturais existentes nos relevos vulcânicos da Região Metropolitana de Fortaleza. São eles (1) os fonólitos, que constituem a maior porcentagem das rochas alcalinas encontradas na área; (2) os traquitos, (3) os tufos, que são os exemplares alcalinos mais raros, já que este tipo de rocha está relacionado aos materiais que faziam parte do antigo edifício vulcânico, ou a blocos de rochas encaixantes carregadas pelo magma durante sua ascensão (e.g. TEIXEIRA, 2007), e (4) essexito porfirito, em baixa quantidade. Essas rochas estão associadas ao um típico vulcanismo continental alcalino-sódico, muito comum em regiões que não sofrem processos de separação de placas (TEIXEIRA, 2007; DANA, 1984.).

Dos quatro tipos de rochas, os fonólitos e os traquitos são as mais comuns. Dana (1984) define os fonólitos como rocha afanítica de cores cinza a esverdeada, constituída por fenocristais de sanidina, principalmente, com granulação variando de fina a muito fina e pobre em sílica, manifestando uma maior presença de feldspatóides. O traquito é uma rocha composta principalmente de feldspato alcalino, com carência de quartzo, usualmente apresentando textura porfirítica com fenocristais de sanidina de tamanho milimétrico e de cor avermelhada.

Segundo Guimarães et al. (1982), petrograficamente os fonólitos formam os necks, enquanto os traquitos formam os diques. Texturalmente, as rochas apresentam textura fluidal, com fenocristais e cristais aproximadamente alinhados seguindo a direção preferencial do 
movimento da lava. Essa textura foi observada em quase todas as ocorrências estudadas de fonólitos e traquitos. A razão da diversidade dos tipos de rochas para a Formação Messejana, de acordo com os mesmos autores, está no fato de ter havido mais de uma atividade ígnea na área.

Mota (1998) caracteriza os fonólitos da área como rochas macroscopicamente alteradas superficialmente, devido ao intemperismo físico que predomina sobre o químico na região. Eles apresentam granulação extremamente fina, formada por microcristais opacos, feldspatos, anfibólios, piroxênios e fedspatóides. Microscopicamente apresentam-se com textura afanítica, composta essencialmente por feldspatos alcalinos com alguns minerais acessórios. Quanto aos traquitos, esses se apresentam como rochas bastante alteradas por processos intempéricos, expondo granulação extremamente fina em lâmina delgada, com textura microlítica traquítica constituída por fenocristais de sanidina, plagioclásios, anfibólios, além da presença rara de piroxênios, quartzo e alguns minerais acessórios (MOTA, 1998).

Normalmente, as rochas que constituem os edifícios vulcânicos são de granulometria com cristais praticamente imperceptíveis a olho nu (TEIXEIRA, 2007). Essa situação se confirma no caso dos vulcões analisados, o que se explica pelo fato de que as rochas que compõem as estruturas dos relevos vulcânicos da RMF terem sido formadas próximas à superfície, sendo consideradas subvulcânicas (MOTA, 2005).

Além disso, por se tratar de corpos pequenos, o resfriamento do magma se deu em uma velocidade maior, o que justifica ainda mais a granulometria fina que apresentam (BRAGA, 1981; MOTA, 1998). A granulação fina das rochas da Formação Messejana indica, com efeito, uma profundidade rasa de solidificação do magma. Szabó et. al (2007) definem para estas características uma profundidade de intrusão normalmente não superior a algumas dezenas de metros de profundidade.

Quimicamente a Formação Messejana apresenta, segundo Guimarães (1982), uma baixa quantidade de sílica, o que acarreta um alto teor de álcalis (sódio e potássio). A grande presença de alcális nas rochas, sugerem a origem de um magma mantélico, associado ao manto superior. Elas são incluídas entre as mais alcalinas e sálicas (ricas em sódio) de idade Terciária conhecida no Nordeste (MOTA, 1988, 2005).

A maneira como se processou o magmatismo em superfície é algo difícil de saber. A erupção pode ter sido do tipo explosiva ou efusiva, o que depende do conteúdo em voláteis do magma e da viscosidade (BOILLOT, 1999). No entanto, o alto conteúdo de $\mathrm{Na}_{2} \mathrm{O}$ e $\mathrm{K}_{2} \mathrm{O}$ naturalmente ajuda a baixar a viscosidade do magma (FRANCIS e OPPENHEIRM, 2003), o 
que de certa forma permite inferir a ocorrência de erupção mais efusiva durante o vulcanismo da Formação Messejana, isto é, com pequeno derrame de lava.

\section{Origem dos vulcões cearenses: "hot spot”" ou vulcanismo fissural?}

Os vulcões extintos da RMF tiveram atividade durante o Terciário. Com efeito, Vandoros e Oliveira (1968) determinaram, por meio do método de K-Ar utilizando mineral feldspato potássico oriundo do Serrote Caruru, localizado em Fortaleza, uma idade terciária para essas estruturas. Cordani (1970) pelo mesmo método e para a mesma formação, obteve a idade de 29 Ma, que corresponde ao periodo Oligoceno da era Terciária.

A primeira hipótese para a origem da Formação Messejana é defendida por autores como Moreira (1977), Braga (1981), Guimarães et al. (1982), Almeida et al. (1983,1986, 1988), Brito Neves e Schobbenhaus (2003), que associam a origem desta formação a uma zona de fraturas oceânicas relacionada à expansão do assoalho do oceano Atlântico, através da ascensão de magma ao longo de falhas transformantes. Almeida et al. (1988) foram os pioneiros dessa ideia e defensores desta teoria.

Com efeito, Almeida et al. (1988) dizem que essa zona de fraturas é responsável pelo alinhamento no qual se localizam diversos montes vulcânicos submarinos que corta o Oceano Atlântico no Nordeste do Brasil, como o Atol das Rocas, o arquipélago de Fernando de Noronha e rochas da Formação Messejana. Este alinhamento está orientado aproximadamente segundo o paralelo de $4^{\circ}$ de latitude Sul e $32^{\circ}$ de longitude Oeste (Figura 4 ).

O relevo vulcânico denominado de Morro Caruru, presente na praia Porto das Dunas, em Aquiraz, Ceará (ver Figura 1), representaria a extremidade ocidental do alinhamento de Fernando de Noronha. Almeida et al. (1988) atribuíram a orientação do vulcanismo como progredindo de oeste para leste ao longo da cadeia, o que está de acordo com a informações geocronológicas existentes, que indicam que a Formação Messejana data de $30 \mathrm{Ma}$, enquanto as formações de Fernando de Noronha datam de 11 e 2 Ma (ALMEIDA et al., 1988).

Entretanto, existe também uma segunda hipótese, apresentada por autores como Fodor et al. (1998), Thomaz-Filho et al. (2000) e Misuzaki et al. (2001). Eles acreditam que a origem da Formação Messejana tenha se dado através da ação de um hot spot (e.g., pontos quentes estacionários existentes no interior do manto, que registram atividades ligadas à ascensão de material magmático, ou plumas de convecção originadas em profundidades diversas) (TASSINARI, 2007). Esse hotsopt seria o mesmo que teria dado origem à cadeia submarina de Fernando de Noronha. 


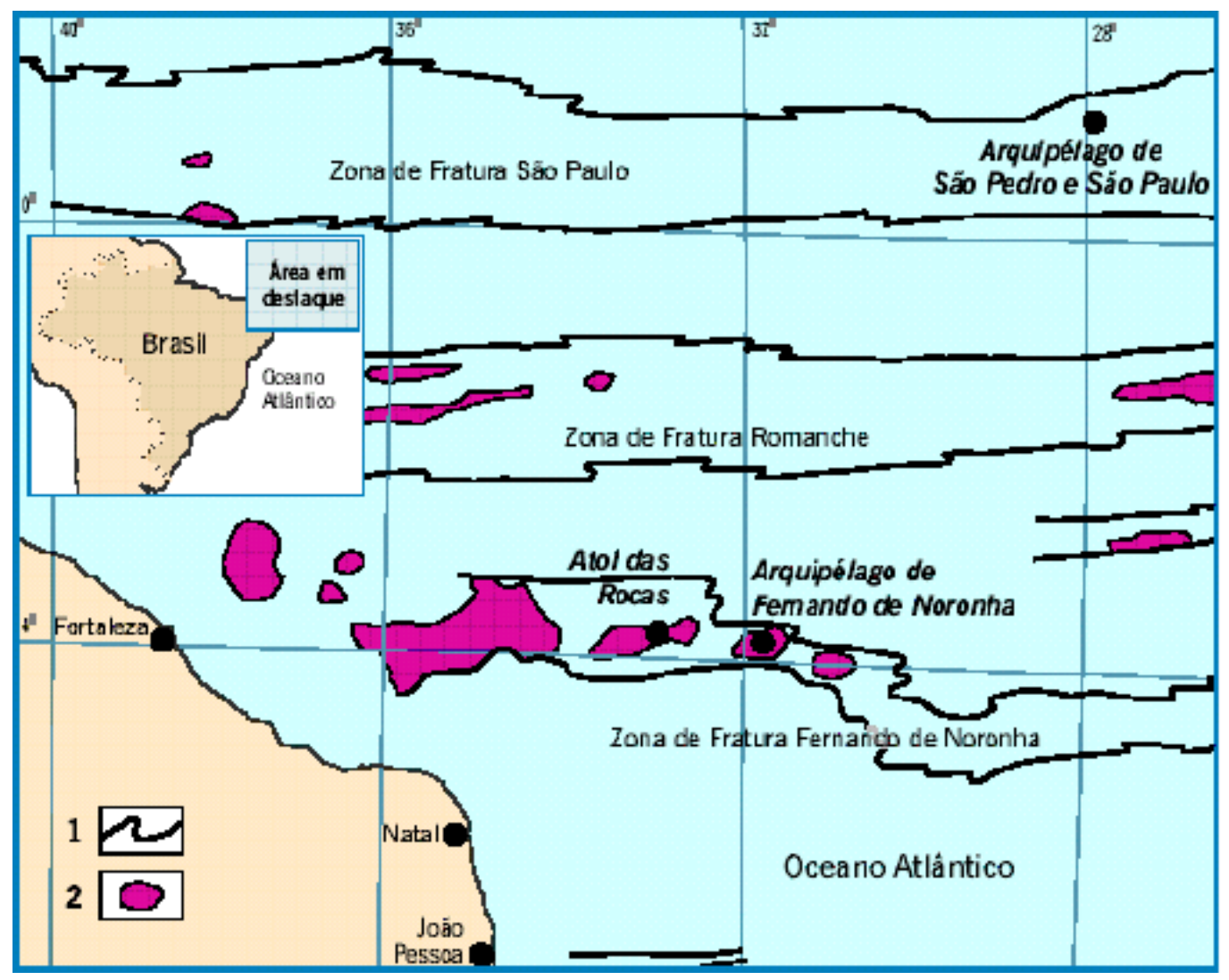

Figura 4. Região oceânica adjacente ao Nordeste brasileiro. Observa-se o Arquipélago de São Paulo na zona de fratura São Paulo e o possível alinhamento da zona de fratura entre Fernando de Noronha e a Formação Messejana. 1 - Limite de zonas de fratura. 2 - Rochas magmáticas. Fonte: Almeida et al. (2006).

Porém, o arquipélago representaria a última fase de evolução desta pluma mantélica, em razão do deslocamento da placa sul-americana sobre essa anomalia térmica. Além do magmatismo terciário que ocorre no norte do Ceará, esse processo seria ainda responsável pelo magmatismo nos Estados do Rio Grande do Norte e de Pernambuco (ALMEIDA et al., 1996).

De acordo com Mizusaki et al. (2001), as rochas magmáticas do período Terciário ocorrem longitudinalmente à margem equatorial do Nordeste do Brasil, sendo interpretadas como efeitos tardios dos processos tectônicos associados com a divisão da placa da América do Sul da placa da África no Cretáceo Superior. Thomaz-Filho et al. (2000), defensores da teoria, afirmam que do Cretáceo superior para o Terciário, durante a fase de deriva na evolução do oceano Atlântico Sul, as manifestações vulcânicas introduzidas com características alcalinas, 
assim como a direção linear apresentada pelos sucessivos eventos, sugerem atividade de hot spot.

No Brasil, os melhores exemplos de processos semelhantes seriam os alinhamentos vulcânicos de Fernando de Noronha (Formação Messejana, Atol das Rocas e o arquipélago de Fernando de Noronha) e as rochas alcalinas de Poços de Caldas/Cabo Frio associadas com a cadeia de Vitória-Trindade, localizada na área oceânica (Figura 5).

Entre as principais razões pela qual esta hipótese pode ser verdadeira acha-se as características morfológicas e geoquímicas dos edifícios vulcânicos da Formação Messejana. Nas erupções fissurais via de regra, o magma ascende por fissuras profundas na crosta e não condiciona normalmente a formação de relevos pontuais (cônicos ou dômicos) (FRANCIS e OPPENHEIRM, 2003), o que ocorre com as formas observadas nos relevos da Formação Messejana. Além disso, este tipo de atividade fissural está ligado sobretudo, a cadeias mesooceânicas (TEIXEIRA, 2007).

Em contrapartida, as erupções associadas com hot spot originam edifício vulcânico condicionado à presença de um magma de composição mais félsica (alcalina), confirmado através de análises químicas para as rochas desta formação (ALMEIDA, 1986). Até mesmo Almeida (1986), definindo a orientação da zona de fraturas de Noronha como sendo leste-oeste, chamou a atenção para o fato de que na zona costeira próxima à Formação Messejana não se observou orientações estruturais nesta mesma direção $(E-W)$, o que não permite uma definição precisa quanto a origem associada a uma zona de fraturas oceânicas. 


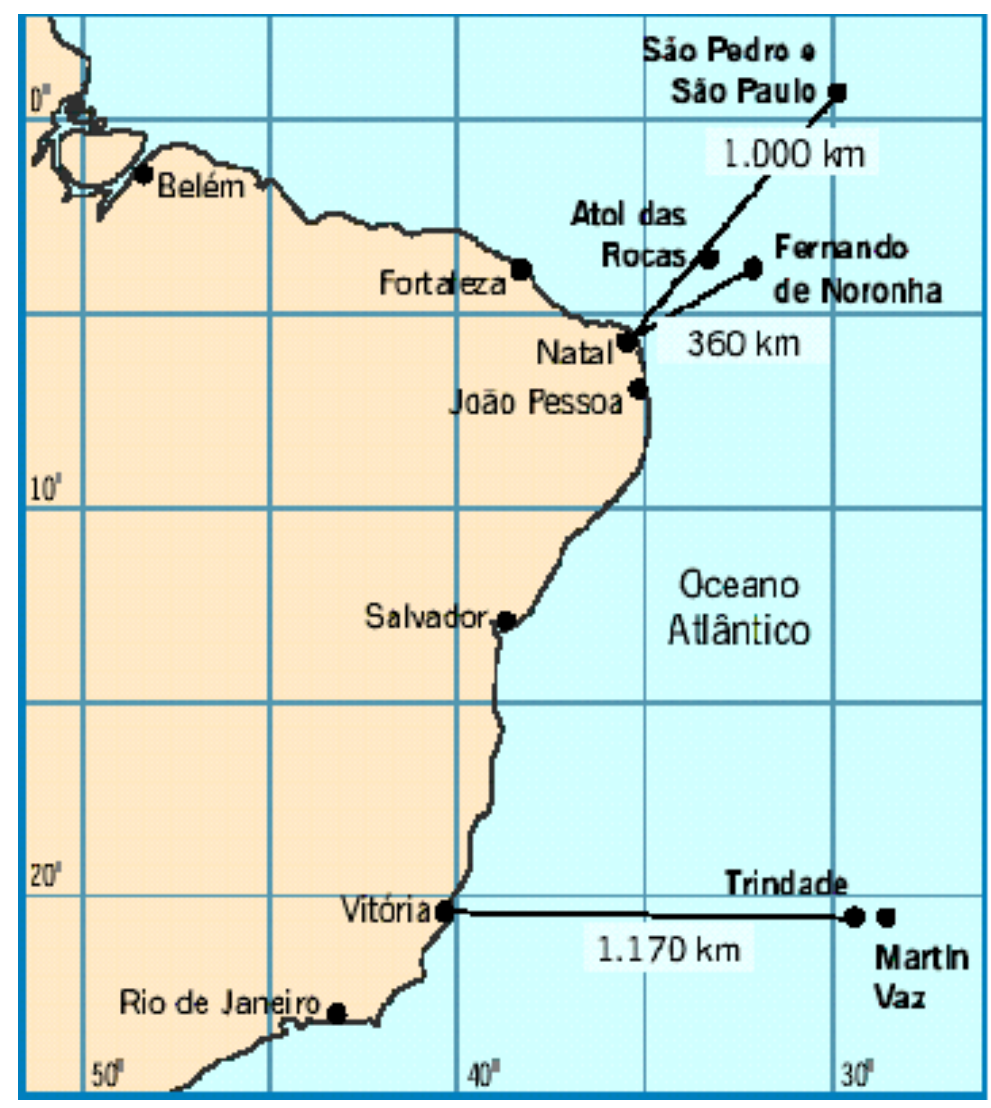

Figura 5. Localização das principais ilhas vulcânicas e arquipélagos oceânicos brasileiros e a distância das capitais mais próximas. Ao norte e sul, a posição das Ilhas oceânicas sugere a ocorrência de pontos quentes nas suas origens.

Reforçando mais ainda a ideia, em trabalho posterior, Almeida (2006), após analisar a atuação de hot spots, sugeriu que em meados do Eoceno (53-33.7 Ma) um hot spot teria surgido na região de Fortaleza, ao longo da borda afinada e fraturada da crosta continental em contato com a oceânica, originado por anomalia térmica na astenosfera. Segundo ele, o hot spot teria produzido na sequência o vulcanismo representado pelas rochas alcalinas que se expõem nesse distrito magmático. Ele conclui dizendo que com o prosseguir da deriva da placa para oeste, esse ponto quente teria dado origem à cadeia vulcânica marinha, presente na zona de fraturas de Fernando de Noronha, que adentra a margem continental emersa na região de Fortaleza.

Para melhor ilustrar essa anomalia térmica na área, Carneiro et al. (1989) chamam atenção para anomalias geotérmicas situada na região centro-norte do Ceará, estendendo-se desde o litoral até o limite sul do Maciço de Tróia-Tauá (centro-oeste do Estado) e ao norte de Fortaleza. Os autores supuseram haver correlação entre as anomalias geotérmicas descritas e as áreas de 
atividades ígneas terciárias do Nordeste Oriental. Para eles, a área do magmatismo pode ser entendida como uma região ainda submetida a condições de resfriamento e de perda de calor em ampla extensão decorridos cerca de $30 \mathrm{Ma}$. Desta forma, a região teria tido locais propícios ao fenômeno de hot spot. Essa parece ser, portanto a origem mais plausível para o vulcanismo terciário que originou a Formação Messejana e os vulcões do Ceará.

\section{Geomorfologia dos vulcões cearenses}

Tanto os necks quanto os diques passaram por processos superficiais denudacionais, os quais originaram formas particulares. De maneira geral, os necks representam serrotes de formas circulares, cônicas e elipsoidais, com dimensões de até $1,5 \mathrm{~km}^{2}$. Eles foram designados por Saadi e Torquato (1992) como Serrote Preto, Arriscada, Porção, Pão-de-Açucar, Salgadinho, Japarara, Ancuri e Caruru.

Quanto aos diques, aqueles de maior porte constituem ondulações ou cristas estreitas e alongadas, com extensão não superior a 1 km e largura máxima de 50 metros. Os menores diques não podem ser representados nos mapas geológicos regionais devido às suas dimensões reduzidas.

Exemplos bem representativos desse conjunto de relevos vulcânicos são: o Serrote Caruru, situado no segmento oeste de Aquiraz, entre Eusébio e Fortaleza, na Praia Porto das Dunas, apresentando 350m de extensão e 59m de altitude (Figura 6A); o Serrote Ancuri, situado no segmento norte de Itaitinga, apresentando aproximadamente $2 \mathrm{Km}$ de extensão e $119 \mathrm{~m}$ de altitude (Figura 6B); o Serrote Pão-de-Açúcar, situado em Caucaia, apresentando dimensão reduzida, com apenas 49m de altitude e 160m de comprimento (Figura 6C); o Serrote Japarara, localizado na extremidade sul de Maranguape, medindo aproximadamente $2 \mathrm{~km}$ de extensão e 450m de altitude, apresentando vertentes dissimétricas e topo aguçado (Figura 6D). Os três primeiros relevos (Figura 7) serão detalhados do ponto de vista geomorfológico a seguir. 


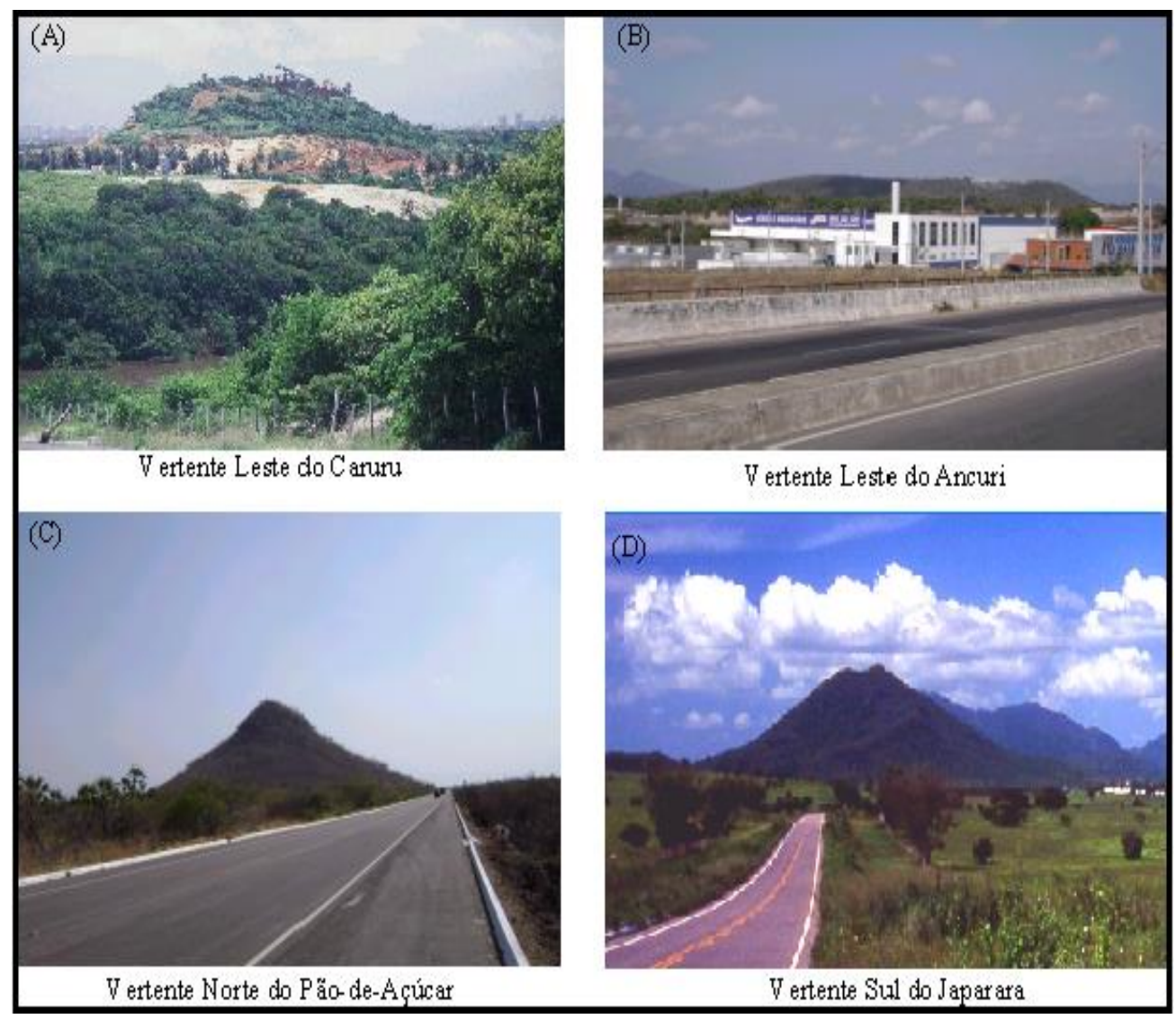

Figura 6. Relevos vulcânicos da Região Metropolitana de Fortaleza

O relevo vulcânico do Caruru situa-se na divisa entre o município do Aquiraz e o limite sudeste de Fortaleza. Apresenta-se de fácil acesso, à margem direita da Avenida Litorânea, que liga a capital à praia do Porto das Dunas, e está limitado pelas coordenadas geográficas $38^{\circ} 25^{\prime} 466^{\prime \prime}$ de longitude Oeste e 3\%49'077' de latitude Sul.

Vandoros e Oliveira (1968) foram os primeiros pesquisadores a estudar o Serrote Caruru, descrevendo a petrologia deste relevo como sendo formado por fonólitos que se situam na zona costeira, próximo ao estuário do Rio Pacoti, sendo completamente circundado pela cobertura cenozoica da Formação Barreiras (Figura 8) e por depósitos eólicos dunares (dunas móveis e fixas) e fluviais. Assim, apresenta um quadro bastante rico do ponto de vista da paisagem geomorfológica que o cerca. 


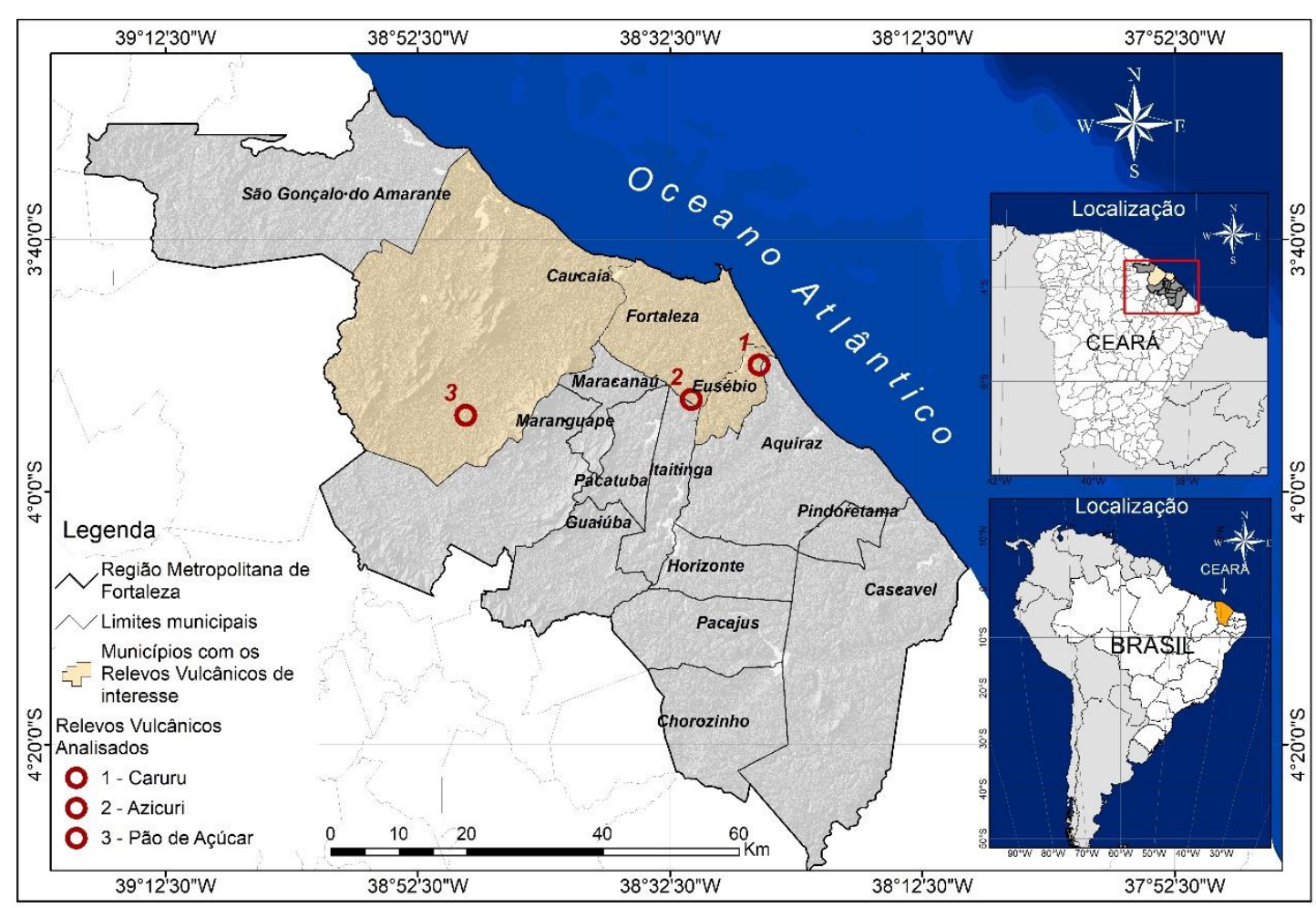

Figura 7. Localização dos relevos vulcânicos objeto de análise nesse trabalho.

O Monte Caruru apresenta-se em forma de domo arredondado, com topo relativamente plano e vertentes relativamente íngremes, mas com certo grau de convexização. Desde o Oligoceno submetido às intempéries, que erodiu parcela da feição, ele não apresenta as mesmas formas originais. No entanto, a caracterização geomorfológica do Caruru em forma topográfica de abóbada nos remete a definir este relevo como um exemplo típico de domo vulcânico. Tais características estão associadas a uma alta viscosidade do magma, fazendo com que a lava, em vez de fluir, acumule-se no interior do edifício vulcânico, criando a feição dômica com encostas íngremes e topo relativamente plano (Figuras 9 e 10).

No entorno do corpo pode-se observar uma fina camada de sedimentos agregados bastante oxidados, resultado do intemperismo químico, além de blocos arredondados e semiarredondados (matacões) oriundos principalmente do intemperismo físico (termoclastia) ao longo do tempo (Figura 11).

Em alguns dos relevos da Formação Messejana é possível visualizar o encaixe da rocha vulcânica com o embasamento cristalino. Porém, tratando-se do Caruru, a possibilidade de observar este encaixe torna-se muito difícil em razão deste relevo estar situado em uma área de 
tabuleiro litorâneo, circundado pela Formação Barreiras (ver Figura 8) e sedimentos quaternários.

Os sedimentos quaternários tanto são oriundos dos aluviões transportados pelo Rio Pacoti quanto de areias transportadas pelos ventos. Na parte sudeste do relevo a presença destes detritos eólicos é tão evidente que às vezes o relevo confunde-se com as dunas presentes na área, como mostra a Figura 12.

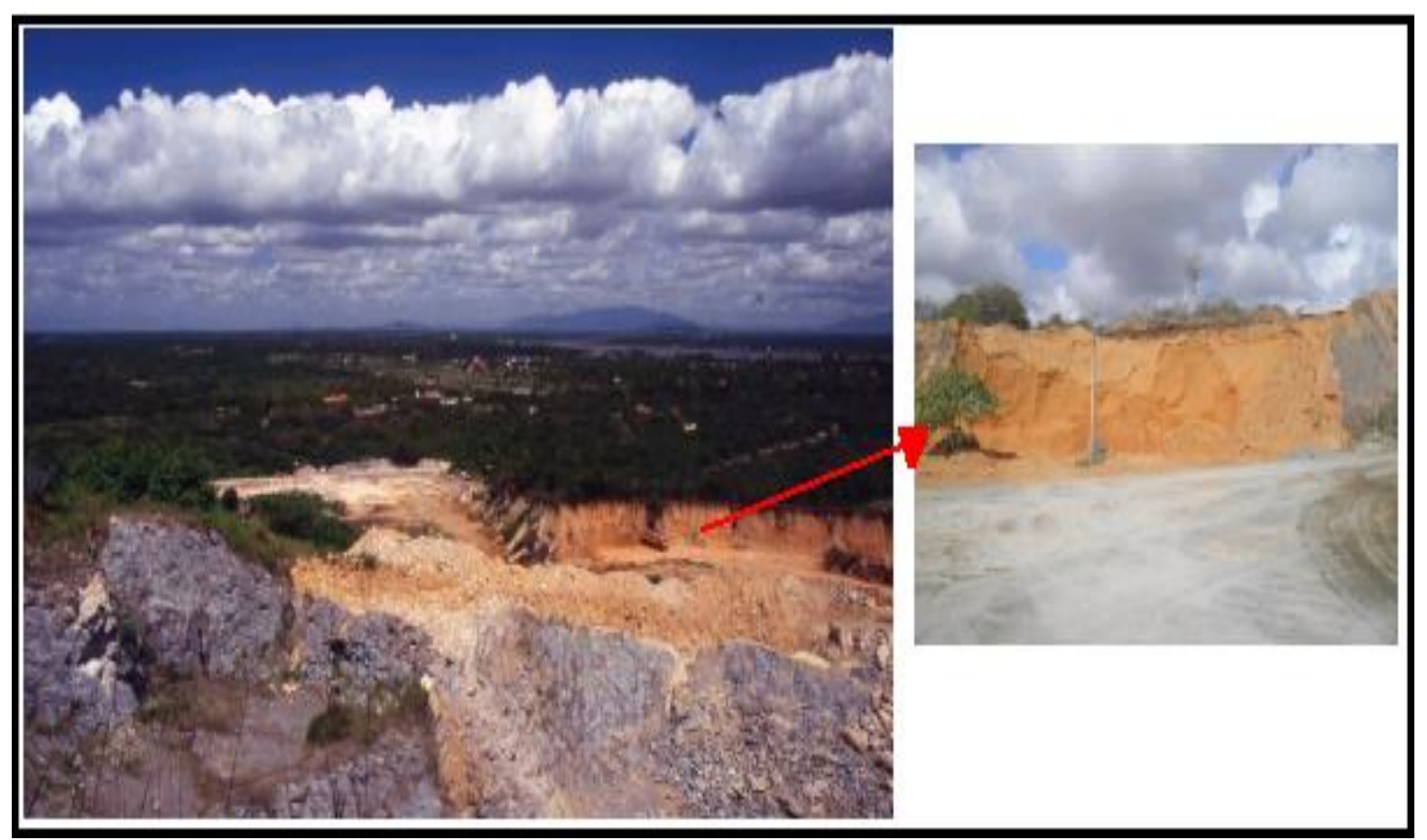

Figura 8. Visão do topo do Caruru e os depósitos Barreiras ao sudoeste da área. Fotos: Costa, A.T.

O Monte Caruru encontra-se profundamente alterado em função da atividade de mineração que implica na exploração da sua rocha vulcânica por várias décadas, principalmente para a produção de brita, visando abastecer o mercado de Fortaleza (COSTA, 2008). A mineração já destruiu as vertentes oeste e norte do relevo, e continua ativamente desmontando a feição, pois a produção atinge valores da ordem de $20 \mathrm{mil} \mathrm{m}^{3}$ de brita por mês (DNPM, 2016). 


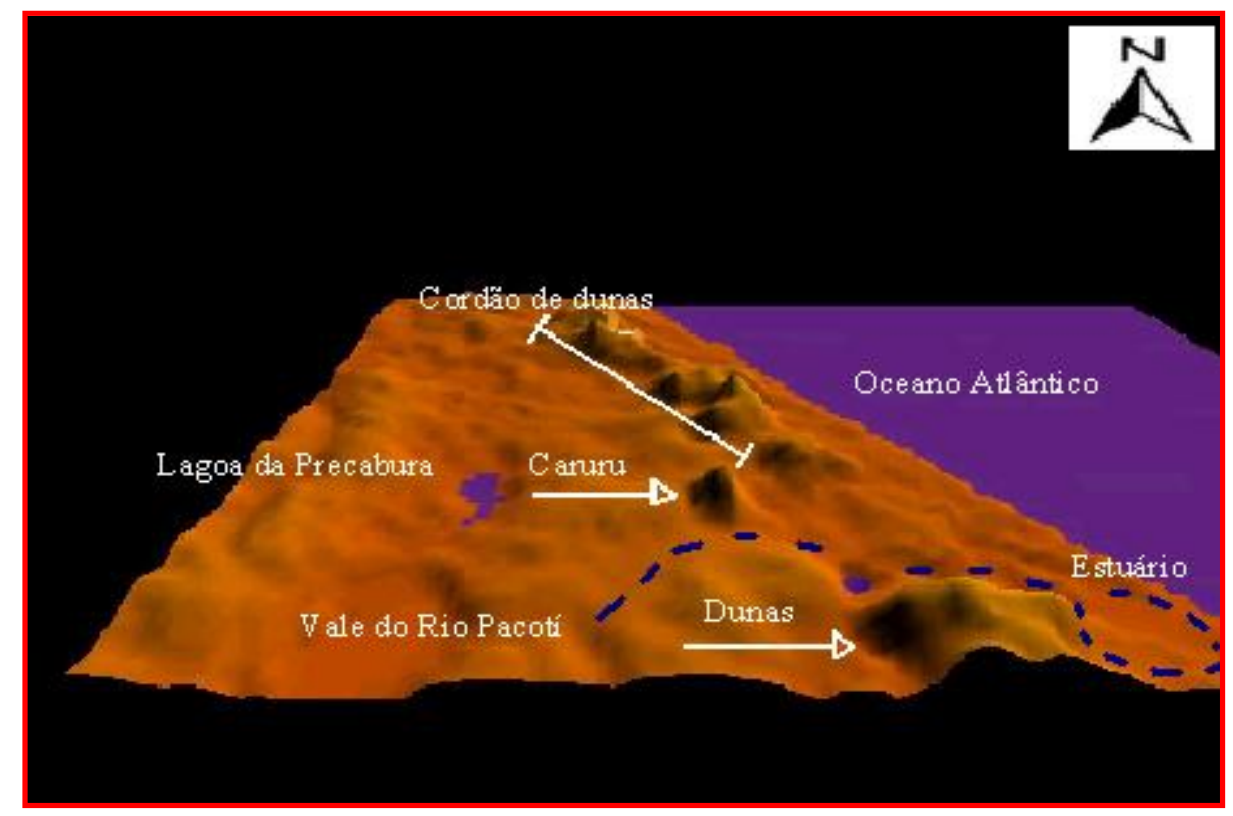

Figura 9. Visão 3D da paisagem do entorno do Monte Caruru (criado através do programa Global Mapper versão 2015)

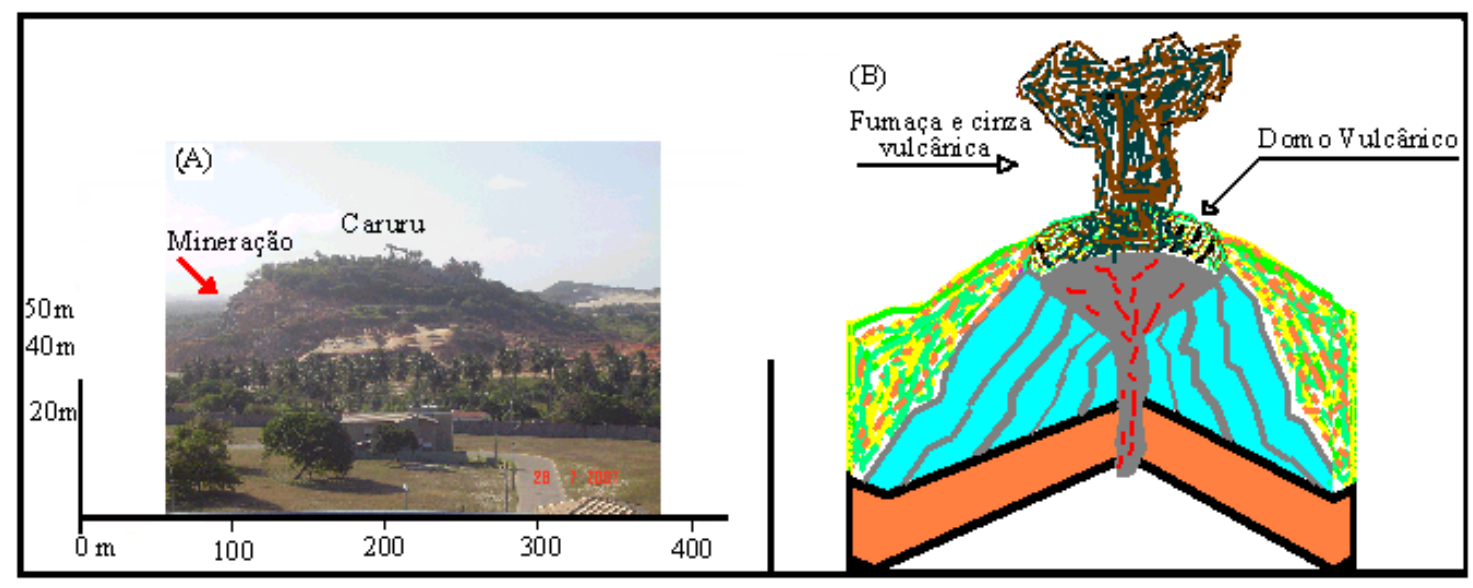

Figura 10. Visão da vertente leste do Caruru à esquerda, e esquema de formação de um domo vulcânico à direita. 


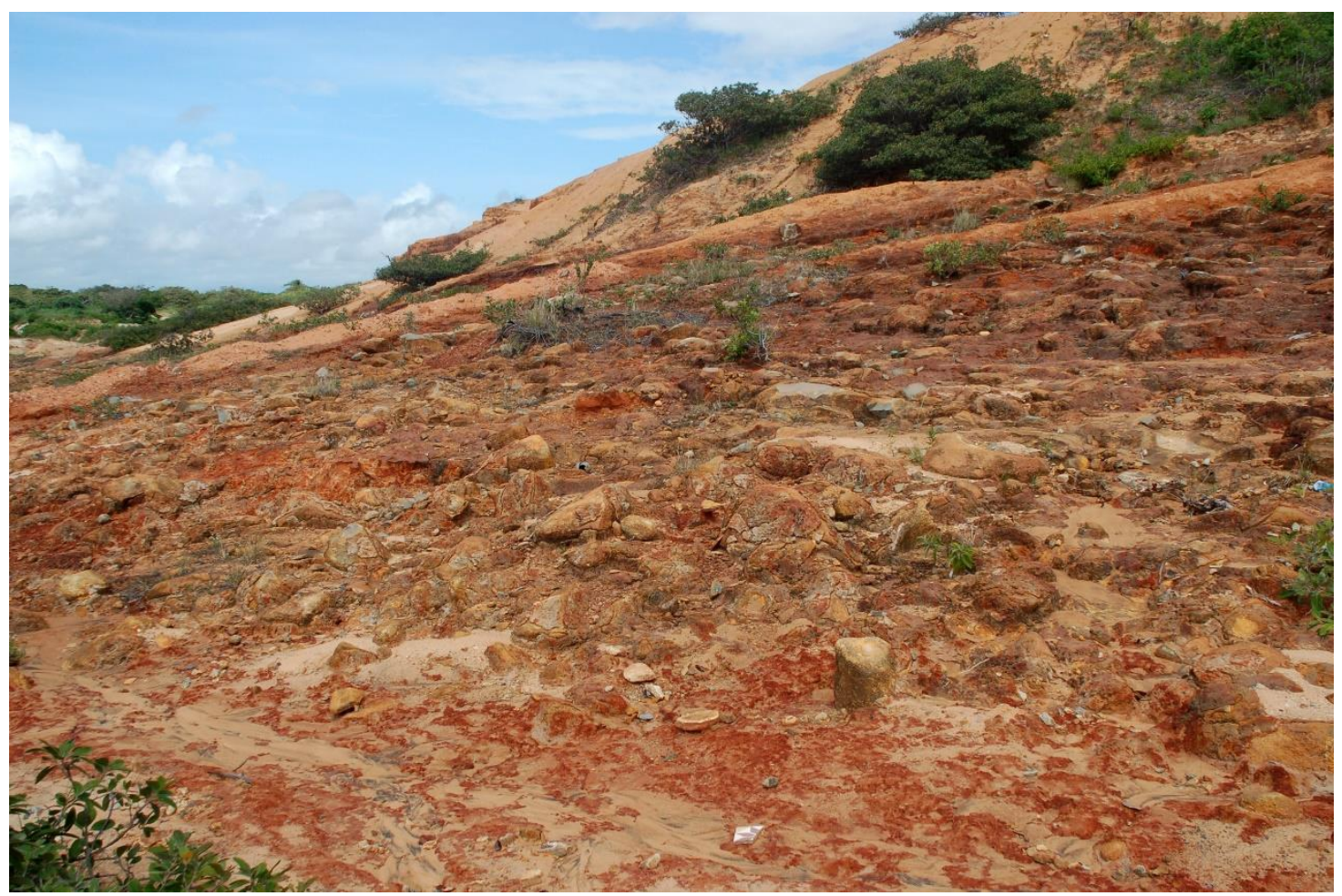

Figura 11. Blocos arredondados de fonólitos encobertos por carapaças endurecidas resultantes do intemperismo químico na vertente leste do Monte Caruru. Foto: Costa, A.T.

Quanto ao Serrote Ancuri, este localiza-se a $9 \mathrm{Km}$ ao sul de Messejana (parte sul de Fortaleza), no povoado homônimo, distando aproximadamente $1 \mathrm{~km}$ a margem direita da BR116 (ver Figura 7). O relevo esta inserido em uma área bem servida de vias de transporte e meios de comunicação, e encontra-se limitado pelas coordenadas geográficas de 38 31'53" de longitude Oeste e $3^{\circ} 53^{\prime} 46^{\prime \prime}$ de latitude Sul.

Segundo Braga (1981), a rocha que forma este corpo é do tipo fonólito rico em sodalitanefelina, o terceiro mais rico em sílica e um dos mais pobres em sódio e potássio dentre os relevos da Formação Messejana. As rochas apresentam textura traquitóide extremamente bem desenvolvida. Trata-se de uma rocha homogênea, maciça, cinza-escura a castanho quando alterada. No entorno do relevo, ocorrem blocos e matacões dispersos em superfície e englobados na massa de talús. 


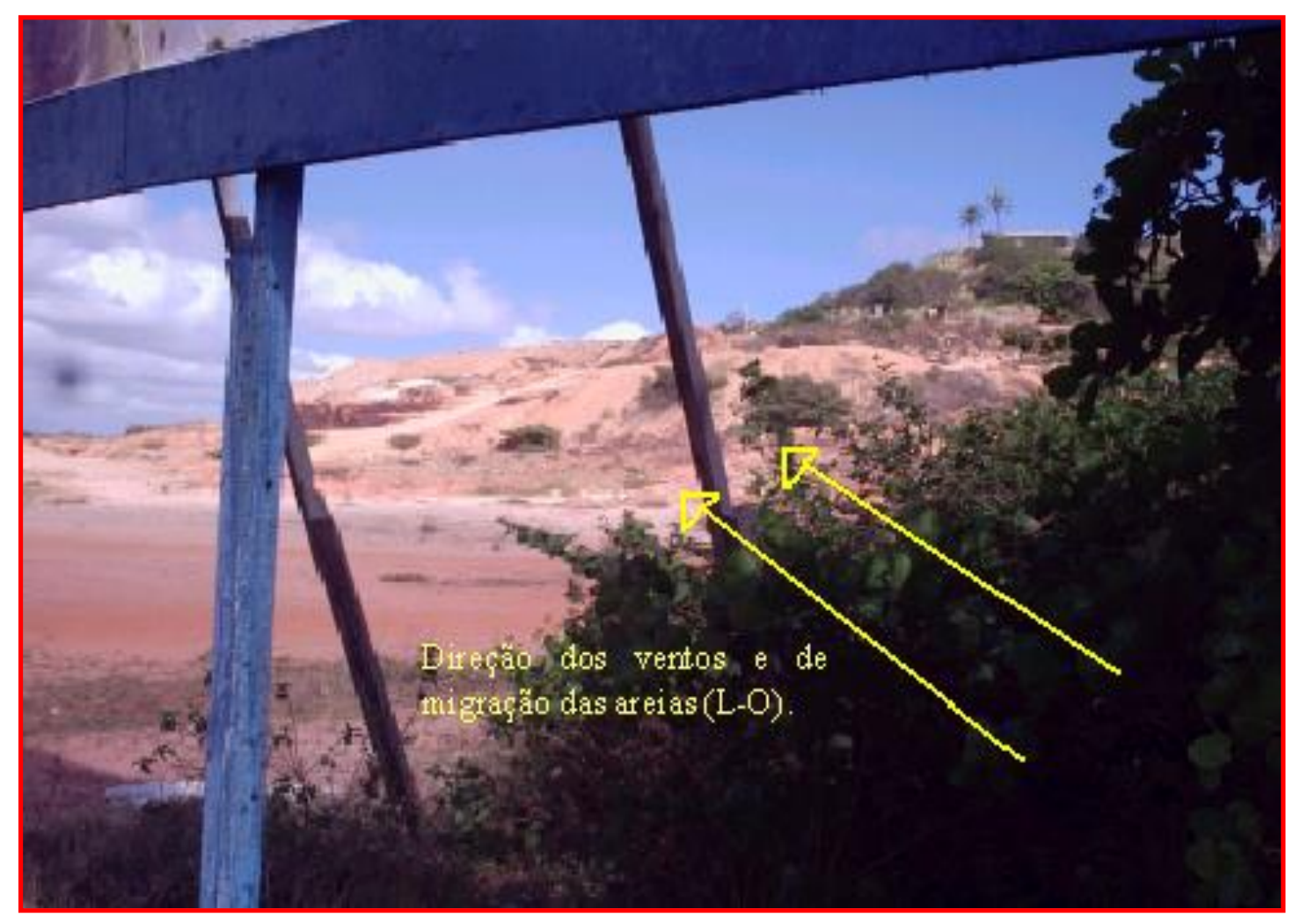

Figura 12. Areias eólicas (dunas) acumuladas na base do Monte Caruru. Foto: Costa, A.T.

O corpo ígneo do Ancuri, mesmo se localizando em um ambiente geológico cenozóico, não sofre influência de depósitos eólicos ou de morfologia dunares como ocorre no Caruru, por estar mais distante do litoral. O relevo localiza-se a $20 \mathrm{~km}$ do litoral, sendo, portanto, todo inserido no contexto dos tabuleiros costeiros. Apresenta-se, desta forma, circundado por sedimentos tercio-quaternários da Formação Barreiras, sedimentos colúvio- eluviais e flúvioaluvionares. Este fato explica a homogeneidade morfológica da área e o destaque topográfico apresentado por este relevo (Figura 13). 


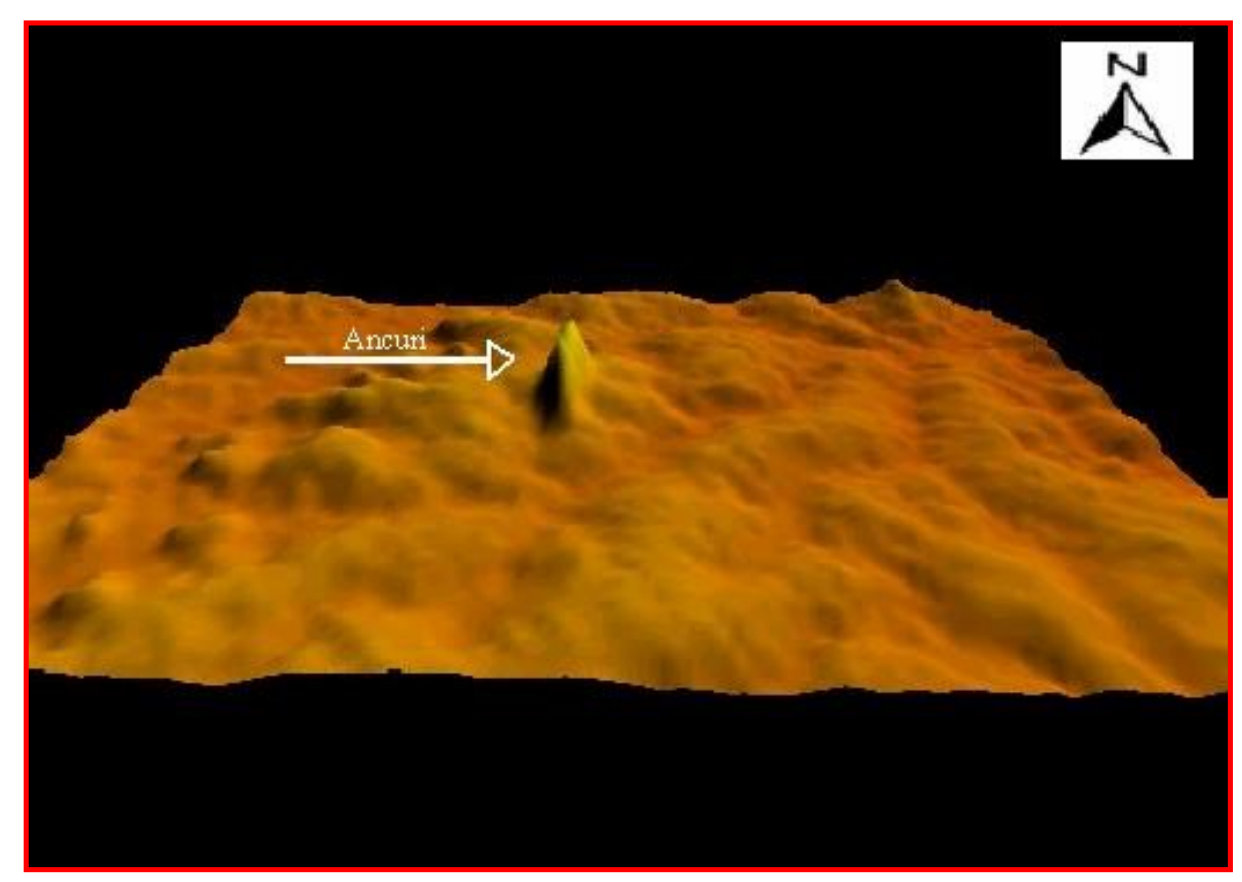

Figura 13. Visao em 3D da paisagem geomorfológica nas proximaidades do Serrote Ancuri (contruído a partir do programa Global Mapper 2015).

A figura 14 indica a existência de um relevo com topo relativamente plano e vertentes simétricas, com contato brusco com a área de tabuleiro a sul, enquanto que a vertente a norte (Figura 14B) decai mais suavemente. Nesse setor B, existe um pequeno pedimento, fazendo com que o contato com os tabuleiros costeiros seja um pouco ondulado.

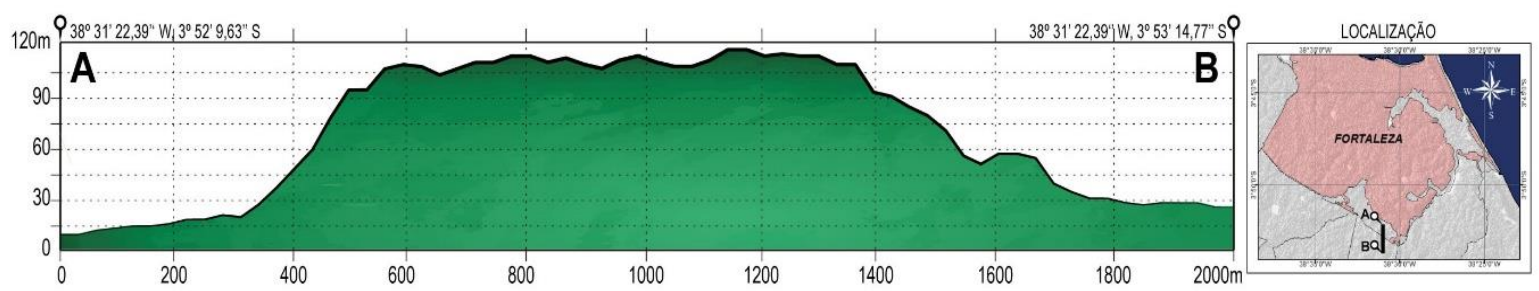

Figura 14. Perfil topográfico do Serrote Ancuri, de direção N-S, mostrando a morfologia de topo e as características das vertentes, caracterizando um domo vulcânico (elaborado a partir do SRTM 2018).

O serrote apresenta uma morfologia em forma de neck elipsoidal, com eixo maior alongado segundo uma direção NE-SW, com aproximadamente $2 \mathrm{~km}$ de extensão, com sua 
altitude máxima em torno de $109 \mathrm{~m}$, sendo $79 \mathrm{~m}$ de altura do relevo propriamente dito. Tal característica elipsoidal pode estar relacionada à presença de uma pequena fratura próximo ao centro vulcânico, sendo possível que o magma no instante de sua solidificação dentro do antigo conduto tenha se espalhado para a lateral, atingindo assim a fratura. Ocorrem diáclases e fraturas verticais, fato que faz imaginar que não houve corrida de lava muito significante.

Quanto ao Serrote Pão-de-Açúcar, ele encontra-se limitado pelas coordenadas geográficas $38^{\circ} 49^{\prime}$ 624' de longitude Oeste e $3^{\circ} 53^{\prime}$ '275' de latitude Sul. Dista cerca de $20 \mathrm{~km}$ de Fortaleza, a oeste, localizando-se no município de Caucaia (RMF), em uma área de fácil acesso, às margens esquerda da BR 020, no sentido Norte-Sul (Km 385). A feição não se apresenta circundada por formações neogênicas, como os dois outros relevos vulcânicos acima analisados.

Segundo Braga (1981), o sodalita-fonólito traquitóide aparece como a rocha dominante neste corpo, que possui características mineralógicas bastante homogêneas, com destaque para a presença de feldspato potássico, sodalita, aegerina, caulinita. $\mathrm{O}$ fonolito traquitóide em menor proporção aparece em blocos pouco abundantes dispostos em torno do corpo.

O sodalita-fonólito traquitóide possui coloração clara e textura afanítica. Em seção delgada foi observada uma matriz com textura extremamente fina, levemente alterada, com presença de material vítreo e ocorrência de feldspato e aegerina, essa rica em sílica, a única em toda a Formação Messejana (GUIMARÃES et al., 1982).

O relevo do Pão-de-Açúcar apresenta em sua base uma forma arredondada. Trata-se de uma elevação topográfica cônica cujo pico atinge 45m acima do nível do mar e 160m de comprimento. Ele pode ser considerado um típico neck fonolítico, ou seja, o antigo conduto vulcânico que ficou descoberto pela erosão (Figura 15). As vertentes apresentam-se íngremes, simétricas, apresentando um topo agudo e convexo e uma forma côncava próxima ao contato com o embasamento.

A forma aguçada também é típica da morfogênese semi-árida atuando sobre relevos residuais, porém a morfologia deste serrote decorre da erosão diferencial, associados aos condicionantes mineralógicos, estruturais e texturais de suas rochas. 


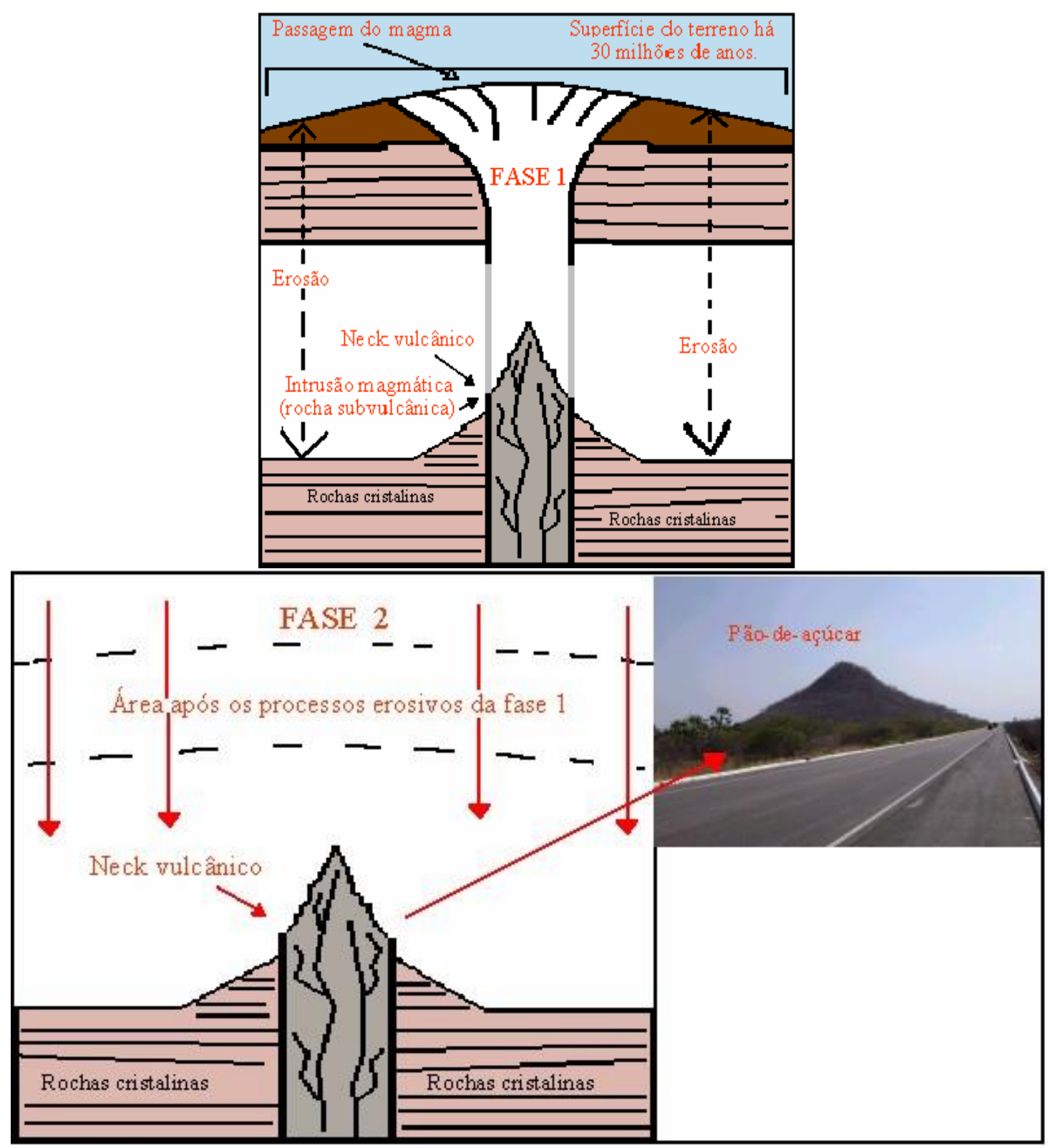

Figura 15. Ilustração mostrando a evolução dos processos erosivos até a exposição das rochas consolidadas dentro de antigos condutos vulcânicos.

As encostas de bases côncavas, por sua vez, refletem a rápida evacuação de detritos. É o único, juntamente com o Salgadinho, com características de cone vulcânico (figura 16A). Fato relevante neste corpo é a grande presença de blocos e matacões (Figura 16B) bordejando praticamente todo o relevo, os quais podem representar fragmentos das rochas que preenchiam o antigo conduto vulcânico. 


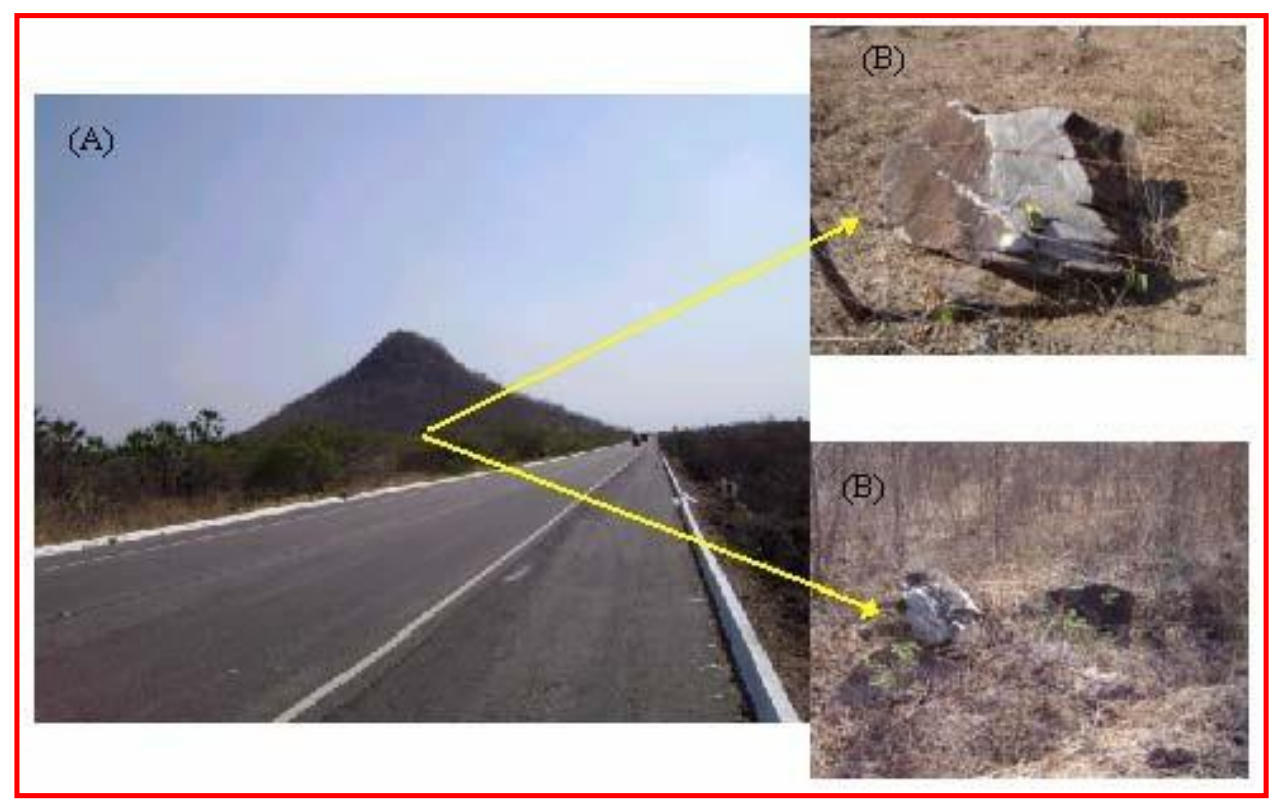

Figura 16. A. Visão norte do relevo Pão-de-Açúcar. B. Blocos e matacões na base da vertente do relevo vulcânico.

O ambiente de inserção do Pão-de-Açúcar é caracterizado por contato direto com o embasamento cristalino, no caso, a sequência migmatito-gnáissica regional do Complexo Caicó, associação litológica constituídas de gnaisses variados, quartzitos e calcários, além de migmatitos com estruturas diversas, desde as mais foliadas até as mais homogêneas (CPRM, 2014).

Por estar mais afastado do litoral em relação aos outros relevos vistos até então, o Pão-deAçúcar está submetido ao clima semi-árido que caracteriza praticamente toda a superfície sertaneja cearense (PEULVAST e CLAUDINO-SALES, 2011), resultando em ocorrência de solo raso e pedregoso, onde a vegetação dominante é a caatinga arbustiva de pequeno porte. As condições hidrológicas da área são representadas por riachos intermitentes de pequena dimensão. Próximo ao ambiente em foco localiza-se o Riacho dos Pinhões, pequeno afluente do Rio Ceará, e o açude Água Boa (Figura 17).

\section{A evolução terciária}

Braun (2005) afirma que por ser uma elevação o vulcão é o primeiro a ser destruído pela erosão. Em adição, o autor coloca que no Brasil nenhuma elevação vulcânica persistiria na 
superfície topográfica por mais de 40 milhões de anos, pois o período Terciário no Brasil caracterizou-se por intensos processos erosivos, formando extensas superfícies de aplainamento, numa situação semelhante ao início do Cretáceo Médio.

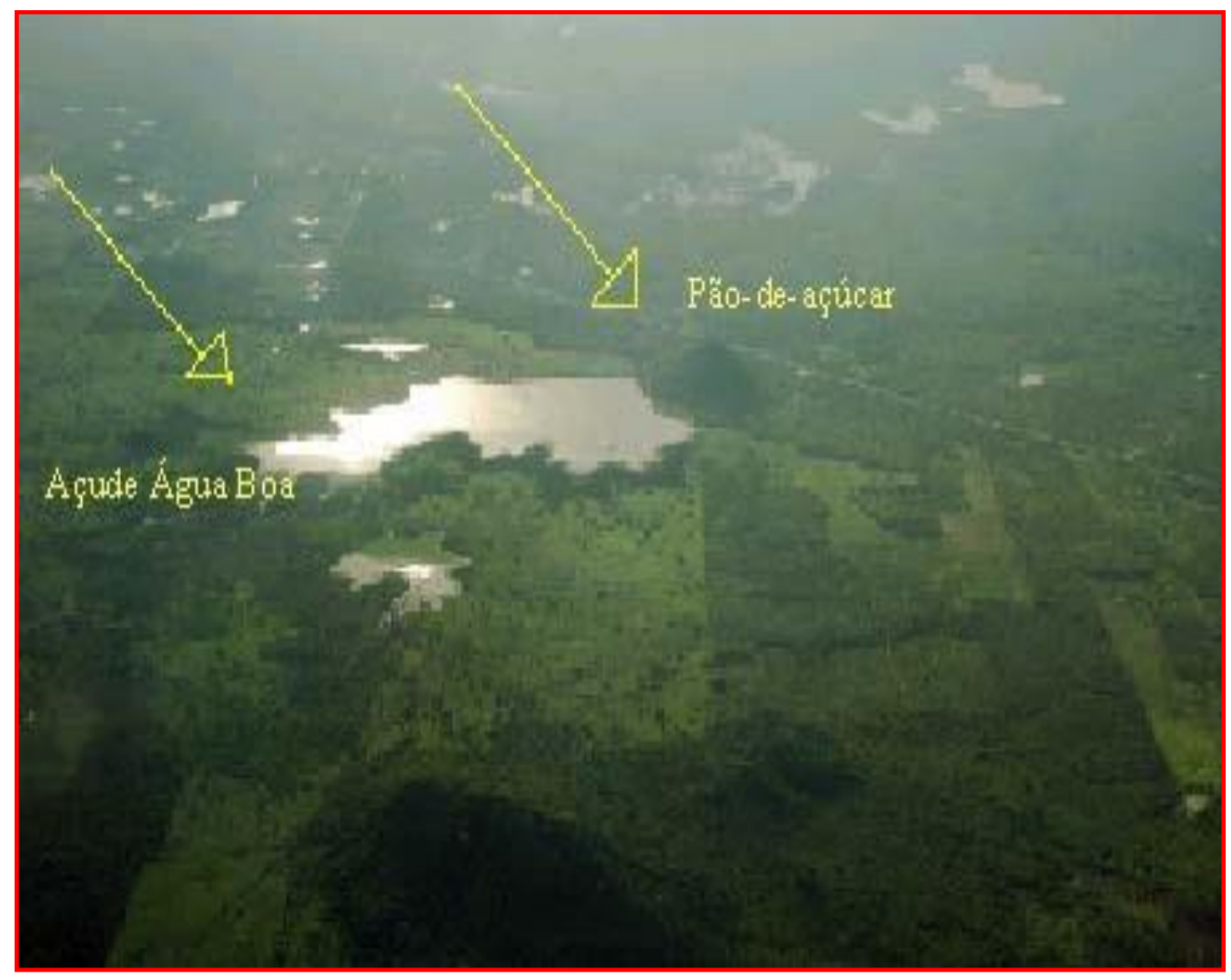

Figura 17. Visão aérea geral do Serrote Pão-de-Açúcar. Observa-se a presença de açude e vegetação de porte arbóreo. Foto: Google Earth, 2019

Tratando de erosão em relevos vulcânicos, Motoki et al. (2005) afirmam que os edifícios vulcânicos perdem sua forma original por meio da erosão, que além de remover os materiais dos edifícios, também remove sedimentos da superfície regional ocasionado pelo abaixamento relativo do nível de base da erosão. Com a passagem do tempo, a erosão chega a estágios avançados, sobressaindo na superfície da terra a estrutura interna, tais como conduto vulcânico, fissura vulcânica, domo vulcânico e câmara magmática.

Os autores concluem que quando a denudação é ainda mais avançada, o edifício vulcânico é completamente eliminado e somente os corpos sub-vulcânicos, tais como diques e necks, são 
expostos. Neste caso, sem edifício vulcânico remanescente, a profundidade da intrusão ou da denudação não é fácil de ser estimada. Tais informações são inferidas e mais precisamente definidas somente por meio de estudos geomorfológicos regionais e datação de traço de fissão em apatita, o que ainda não foi possível realizar.

Quanto às formas presentes atualmente no relevo da RMF, pode se afirmar que estas são as partes de corpos sub-vulcânicos que se solidificaram dentro das antigas chaminés dos vulcões, e que foram expostos à superfície paulatinamente após a parte externa vulcânica sofrer erosão ao longo de milhões de anos. Todos os necks da formação se enquadram perfeitamente nesta situação, especialmente, o do Pão-de-açúcar, devido sua característica cônica.

Constata-se que, após a erosão que destruiu os condutos vulcânicos, certamente os relevos em questão sofreram mudanças de altura, apesar das rochas fonolíticas apresentarem resistência ao intemperismo e apesar do clima regional ser de características semiáridas, portanto, gerando lenta denudação (PEULVAST e CLAUDINO-SALES, 2005).

Tal fato é também atestado em função de que alguns dos relevos vulcânicos (serrotes Caruru e Ancuri) estão próximos do nível de base geral. Deve-se considerar ainda que no Mioceno, com a deposição da Formação Barreiras, o nível de base subiu na área de estudo, sendo rebaixado outras vezes durante o Quaternário em função das mudanças glácio-eustáticas.

Por não apresentar vestígios dos antigos edifícios vulcânicos, torna-se difícil definir a taxa de erosão da Formação Messejana, assim como, estimar a parte ainda que se encontra em subsuperfície destas estruturas. Porém, baseado na conjugação de quatro fatores: I) baixa magnitude crustal, II) baixa amplitude de deformação crustal e baixa topografia do relevo, III) heterogeneidade litológica e IV) predominância de clima semi-árido, Peulvast et al. (2008) calcularam para a região Nordeste do Brasil, em particular para o Estado do Ceará, uma taxa de erosão da ordem de 10m a cada 1 Ma, o que implica em um total de $300 \mathrm{~m}$ de erosão para esta área do Ceará nos últimos $30 \mathrm{Ma}$, época do vulcanismo.

Nesta lógica, baseado nos 59m de altitude do atual relevo, pode-se ilustrar a área em torno do Caruru e a altitude da superfície local-regional há 30 Ma, como mostra a Figura 17. Para o Serrote Caruru, a Formação Barreiras pode servir de importante base para estimar a idade da erosão do edifício vulcânico. O Serrote Caruru possibilita a recomposição da evolução morfológica regional e local, por se apresentar como referência entre paisagem pré-depósito Barreiras e paisagem pós-depósito Barreiras (Figura 18).

Segundo Arai (2006), a origem da Formação Barreiras representaria no mínimo dois episódios, sendo um datado do Oligo-Mioceno (20 Ma) e outro do Mioceno médio (5-7 Ma). 
Considerando-se que a Formação Barreiras foi depositada em contato direto com o neck no caso do Serrote Caruru, o que significa que o edifício vulcânico foi erodido antes da deposição, e considerando-se a idade de $20 \mathrm{Ma}$, ter-se-ia como resultado um intervalo de $10 \mathrm{Ma}$ de anos para o termo dessa erosão.

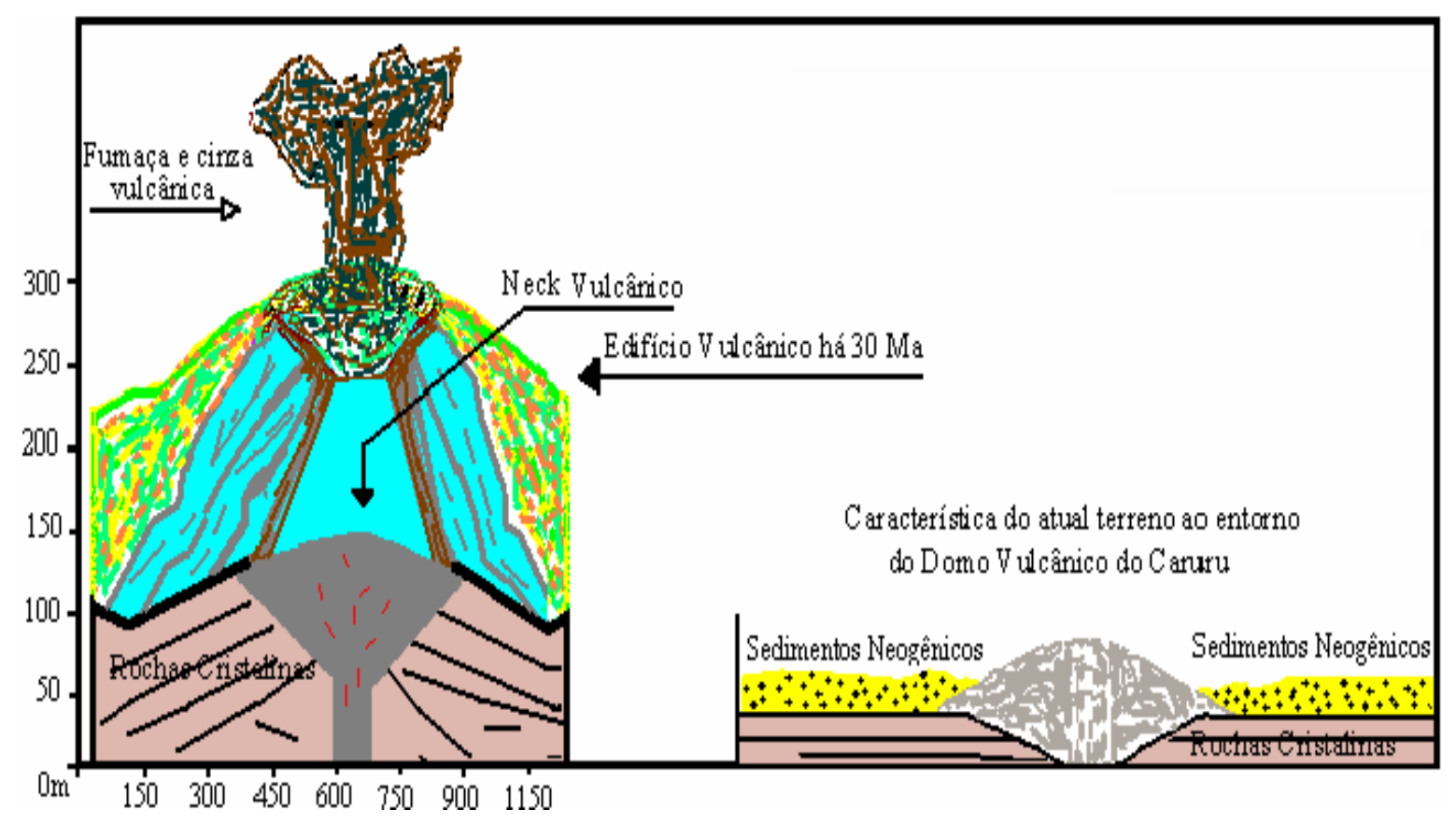

Figura 18. Modelo ilustrativo da evolução cenozoica da área onde se insere o relevo vulcânico Monte Caruru.

Tal cenário caracterizaria elevada rapidez do processo erosivo responsável pela destruição do edifício vulcânico. Caso a Formação Barreiras na área date do Mioceno médio (5-7 Ma), o edifício vulcânico teria tido em torno de 25 Ma para ser destruído pela erosão, o que caracterizaria a ocorrência de processo erosivo bem mais lento.

Ocorrência de rápida erosão de relevos elevados no território do Estado do Ceará foi apontada anteriormente por Peulvast e Claudino-Sales (2004), que identificaram denudação capaz de produzir superfície de aplainamento no entorno do Rift Potiguar (divisa setentrional entre o Ceará e o Rio Grande do Norte) no intervalo de tempo de 12 Ma no Cretáceo Superior. Assim, parece razoável considerar que o primeiro cenário, de erosão do edifício vulcânico em intervalo de $10 \mathrm{Ma}$, seja o mais próximo da realidade.

Essa consideração, de erosão mais rápida dos edificos vulcânicos, são reforçadas pelo fato de que as condições climáticas do Terciário parecem ter sido relativamente próximas das que 
ocorreram no Cretáceo Superior (e.g. Peulvast e Claudino-Sales, 2004). Essas cenários seriam caracterizadas pela ocorrência de condições dominantemente semiáridas com inflexões para intervalos de climas mais úmidos, como parece demonstrar a pequena espessura dos depósitos sedimentares correlativos da erosão no continente - e.g., a Formação Barreiras. Efetivamente, as características sedimentológicas da Formação Barreiras (sedimentos grosseiros com níveis intemperizados) parece comprovar a ocorrência de clima seco com flutuações de pequena duração para condições mais úmidas.

Finalmente, coloca-se que o Monte Caruru, assim como os demais relevos vulcânicos da Região Metropolitana de Fortaleza que se apresentam circundados pela Formação Barreiras, são balizadores geomorfológicos da idade de deposição dessa formação. Tendo sido o vulcanismo datado como tendo ocorrido por volta de 30 milhões de anos, e tendo a Formação Barreiras sido depositada no sopé desses relevos, esse depósito não pode com efeito ser mais antigo que 30 milhões de anos.

\section{CONCLUSÕES}

As estruturas vulcânicas da Região Metropolitana de Fortaleza estiveram durante alguns milhões de anos em condições de sub-superfície, mas ao longo de 30 milhões de anos foram sendo exumadas através dos processos morfogenéticos que permearam a elaboração do relevo regional, resultando em relevos vulcânicos que representam formas singulares na paisagem cearense.

O contato de alguns desses relevos com os sedimentos da Formação Barreiras possibilita a compreensão das mudanças geológicas e geomorfológicas no segmento territorial analisado, mostrando que a área, sobretudo no segmento norte, de essencialmente cristalina, passou a ser sedimentar, o que ocorreu durante o Oligoceno.

Alguns dos relevos (Monte Caruru) passam por processos de exploração mineral com o objetivo de atender o setor da construção civil da Região Metropolitana de Fortaleza, ficando sua morfologia atual controlada por esse tipo de exploração. No momento, a atividade mineradora foi encerrada no Serrote Ancuri, mas pode voltar a atuar a qualquer momento, considerando-se que os relevos vulcânicos do Ceará não contam com nenhuma proteção ambiental específica, e são situados em propriedade privada.

A população de um modo geral desconhece a importância do ponto de vista natural, bem como a origem vulcânica, desses relevos em nosso estado. Com efeito, causa sempre grande 
surpresa e impressão na população a informação acerca da origem das feições, como sendo associadas com vulcanismo.

Do ponto de vista científico, coloca-se que as estruturas e relevos vulcânicos mereciam maior atenção, pois representam eventos e formas únicas, que trazem implicações para a evolução geomorfológica e geológica terciária do Nordeste brasileiro. A pertinência da realização de estudos morfo-estruturais é evidente, para que este tipo de relevo sirva de fonte para futuros estudos de evolução regional.

Em adição, salienta-se que um dos objetivos desse trabalho é chamar a atenção para essas feições, com o objetivo de que eles passem a ser vistos por autoridades governamentais e privadas como importantes elementos da paisagem regional, usando-os como fonte, quem sabe, de visitação turística, obtendo desta forma, uma proteção mais eficiente e duradoura. Nessa perspectiva, seria fundamental que as atividades de mineração fossem encerradas.

\section{REFERÊNCIAS}

ALMEIDA, F.F.M. Geologia e Petrologia do Arquipélago de Fernando de Noronha. Departamento Nacional de Produção Mineral/Diretoria de Geologia e Recursos Minerais, Monografia XIII, Rio de Janeiro, 1955

ALMEIDA, F.F.M. Relações Tectônicas das Rochas Alcalinas Mesozóicas da Região Meridional da Plataforma Sul-Americana. Revista Brasileira de Geociências 13(3): p: 139$158,1983$.

ALMEIDA, F.F.M. Distribuição Regional e Relações Tectônicas do Magmatismo Pós-

Paleozóico no Brasil. Revista Brasileira de Geociências, vol. 16(4): p: 325-349, 1986.

ALMEIDA, F.F.M., CARNEIRO, C.D.R, MACHADO JR, D.L., DEHIRA, L.Z. Magmatismo Pós-Paleozóico no Nordeste Oriental do Brasil. Revista Brasileira de Geociências 18(4): p: 451-462, 1988.

ALMEIDA, F.F.M., CARNEIRO, C.D.R., MIZUSAKI, A.M.P. Correlação do magmatismo das bacias da margem continental brasileira com das áreas emersas adjacentes. Revista Brasileira de Geologia 26 (3): p: 125- 138, 1996.

ALVARES, C.A., STAPE, J.L., SENTELHAS, P.C., de MORAES GONÇALVES, J.L., SPAROVEK, G. (2013). Köppen's climate classification map for Brazil. Meteorologische Zeitschrift 22 (6): 711-728 
ARAI, M. A grande elevação eustática do Mioceno e sua influência na origem do grupo Barreiras. Revista do Instituto de Geociências-USP. São Paulo, vol 6, n.2, p: 1-6, 2006.

BETARD, F., PEULVAST, J.P., CLAUDINO-SALES, V. Caracterização morfopedólogica de uma serra úmida no semi-árido do nordeste brasileiro: o caso do maciço de BaturitéCe. Mercator 6 (12), 107:126, 2007

BOILlOT, G. Géologie des Marges Continentales. 3ª edição. Masson, Paris, 1990.

BRAGA, A.P.G. Geologia da Região Nordeste do Estado do Ceará. Projeto Fortaleza, DNPM Brasília, 1981.

BRANDÃO, R.L. Diagnóstico Geoambiental e os Principais Problemas de Ocupação do Meio Físico da Região Metropolitana de Fortaleza. Projeto Sinfor: CPRM, 1995.

BRAUN, O.P.G. Algumas considerações geotectônicas sobre eventos vulcânicos mesozóico- cenozóicos no Brasil. III Simpósio de vulcanismo e ambientes associados. Cabo Frio, RJ, 2005.

BRITO NEVES, B.B., SCHOBBEnHAUS, C. A Geologia do Brasil no Contexto da Plataforma Sul-Americana. Geologia, Tectônica e Recursos Minerais do Brasil: Brasília: CPRM-Serviço Geológico do Brasil, 2003

CARNEIRO, D.C; HAMZA, V.M; ALMEIDA, F.F.M. Ativação Tectônica, Fluxo Geotérmico e Sismicidade no Nordeste Oriental Brasileiro. Revista Brasileira de Geociências 19(3): 310- 322, 1989.

CARNEIRO, C.D.R., BRITO-NEVES, B.B., AMARAL, I.A., BISTRICHI, C.A. O Atualismo como princípio metodológico em Tectônica. Boletim de Geociências da Petrobrás, 8(2/4):275-293, 1994.

CLAUDINO-SALES, V. Megageomorfologia do Estado do Ceará. São Paulo, Edições NEA, 2016

CLAUDINO-SALES, V. Cenários Litorâneos: Lagoa do Papicu, natureza e ambiente na cidade de Fortaleza, Ceará. Dissertação de Mestrado, Universidade de São Paulo, São Paulo, 1993

CLAUDINO-SALES, V., LIRA, V. Megageomorfologia do Noroeste do Estado do Ceará. Caminhos de Geografia 12 (38), 200-209, 2011

COGERH (COMPANHIA DE GESTÃO DOS RECURSOS HÍDRICOS DO ESTADO DO CEARÁ). Atlas de Recursos Hídricos do Estado do Ceará. http://atlas.srh.ce.gov.br/. 2018. Acessado 12 de novembro de 2018 
CORDANI, U.G; BLAZEKOVIC, A. Idades Radiométricas das Rochas Vulcânicas dos Abrolhos. Anais do XXIV Congresso Brasileiro de Geologia p: 265-270. Brasília, 1970 COSTA, A.T. Análise morfoambiental dos relevos vulcânicos da Região Metropolitana de Fortaleza, Ceará. Dissertação de Mestrado, Universidade Federal do Ceará, 2008 CPRM (COMPANHIA DE PESQUISA EM RECURSOS MINERAIS). Projeto SINFOR. Fortaleza, 1995

CPRM. (COMPANHIA DE PESQUISA EM RECURSOS MINERAIS) Atlas Digital de Geologia e Recursos Minerais do Ceará. Serviço Geológico do Brasil. Escala:1.500.000, Cd Rom, 2003.

CPRM (COMPANHIA DE PESQUISA EM RECURSOS MINERAIS). Geodiversidade do Estado do Ceará. Fortaleza, 2014

DANA, J.D. Manual de Mineralogía. Rio de Janeiro, Livros Técnicos e Científicos, 2 volumes, 1984

DNPM (DEPARTAMENTO NACIONAL DA PRODUÇÃO MINERAL). Anuário Mineral Brasileiro. Brasília, Ministério das Minas e Energia, 2016.

FODOR, R.V; MUKASA, S.B; SIAL, A.N. Isotopic And Trace-Element Indications of Lithospheric And Asthenospheric Components is tertiary Alkalic Basalts, Northeastern Brasil. Lithos (43) p: 197-217, 1998

FRANCIS, P., OPPENHEIMER, C. Volcanoes. Oxford University Press, 2003

FUNCEME (FUNDAÇÃO CEARENSE DE METEOROLOGIA). Postos pluviométricos. http://www.funceme.br/index.php/areas/23-monitoramento/meteorol\%C3\%B3gico/572-

postos-pluviom\%C3\%A9tricos. Acessado 15 de novembro de 2018

GUIMARÃES, I.P.; SIAL, A.N.; FILHO, A.F.S. Petrologia e Geoquímica da Província Alcalina Terciária Fortaleza, Ceará. XXXII Anais do Congresso Brasileiro de Geologia p: 577-588. Salvador-Ba, 1982.

IMPLANCE (INSTITUTO DE PLANEJAMENTO DO ESTADO DO CEARÁ). Atlas do Ceará. Fortaleza, 1989.

IPECE. Mapa da Região Metropolitana de Fortaleza. Fortaleza, 2004. http://www2.ipece.ce.gov.br/publicacoes/Anuario_2004/mapas/pdf\%B4s/RMF.pdf. Acessado 17 de novembro de 2018

LEINZ, V.; AMARAL, S.E. Geologia Geral. São Paulo: Nacional, 1987.

LIMA, C.C.U. O neotectonismo na costa do Sudeste e do Nordeste brasileiro. Revista de ciência e tecnologia (15), p: 91-102, 2000. 
MARTINS, G., OLIVEIRA, D.C. O Enxame de Diques rio Ceará-Mirim no Contexto da Abertura do Oceano Atlântico. Revista de Geologia da UFC. Vol. 5, 51 a 78. Fortaleza, 1992. MATOS, R.M.D.. Tectonic evolution of the Equatorial South Atlantic. American Geophysical Union, Geophysical Monograph. 115:331-354, 2000.

MIZUSAKI, A.M.P.; FILHO, A.T.; MILANI, E.J.; CÍCERO, P. Mesozoic and Cenozoic Igneous Activity and its Tectonic Control in Northeastern Brasil. Jounal of its South American Earth Sciences, Vol(5) p:183-198, 2001.

MOTA, R.F. Geologia e Diagnóstico Geoambiental da Região das Pedreiras de Itaitinga, Estado do Ceará. Dissertação de Mestrado, departamento de Geologia, UFC, 1998.

MOTA, R.F. Estudos Geológicos-Geofísicos da interface água doce/água salgada em aquííferos da Formação Barreiras no litoral da Região de Caucaia-Pecém/CE-R.M.F. Tese de Douturado.Universidade Federal da Bahia, Salvador, Bahia, 2005.238p.

MOTOKI, A. Relação entre as texturas de rochas vulcânicas e estruturas de corpos vulcânicos e sub-vulcânicos: exemplos do Brasil, Argentina e Chile. In: III SIMPÓSIO DE VULCANISMO E AMBIENTES ASSOCIADOS. Anais p. 387-392, 2005.

PEREIRA, R.C.M; SILVA, E.V. Solos e vegetação do Ceará; Características gerais. Um Novo Olhar Geográfico. Org: DA SILVA, J.B. (et. al). Fortaleza, Ed: Edições Demócrito Rocha, 2005.

PEULVAST, J.P., CLAUDINO-SALES, V. Surfaces d'aplanissement et géodynamique. Géomorphologie: relief, processus, environnement 11 (4), 249-274, 2005.

PEULVAST, J.P., CLAUDINO-SALES, V. Stepped surfaces and paleolandforms in the Brazilian Nordeste Northeast. Geomorphology 65, 89-122, 2004

PEUlVAST, J.P., CLAUDINO-SALES, V., BETARD, F., GUNNEL, Y. Low postCenomanian denudation depths across the Brasilian Northeast: Implications for longterm landscape evolution at a transform continental margin. Global and Planetary Change 62, 39-60, 2008.

SAADI, A; TORQUATO, J.R. Contribuição a Neotectônica do Estado Ceará. Revista de Geologia da UFC. Vol. 5: 5 a 38. Fortaleza, 1992.

SABADIA, J.A.B; CASAS, A. Geofísica ambiental na grande Fortaleza: experiências com a utilização de técnicas não invasivas (“FDEM" 31 e 34) em estudos de poluição das águas subterrâneas. Revista de Geologia da UFC, vol. 16, 63-70. Fortaleza, 2003. 
SAlgADO-LABOURIAU, M. L. História Ecológica da Terra. São Paulo, Edgard Blucher, 1998.

SANTOS, J.O; SOUZA, M.J.N. Diagnostico da bacia hidrográfica do rio Cocó-região metropolitana de Fortaleza-Ce. Anais XII simpósio brasileiro de geografia física aplicada, p.657-673, Natal-RN, 2007.

SEMACE._Zoneamento ecológico econômico do Ceará-zona costeira. Fortaleza, SemaceUFC, 2006.

SZABÓ, G.A.J. et al. Rochas ígneas. In: TEIXEIRA, W et al (org). Decifrando a terra. p: 328346. São Paulo, oficina de textos, 2007.

TASSINARI, C.C.G. Tectônica global. In: TEIXEIRA, W et al (org). Decifrando a terra. p: 97-111. São Paulo, oficina de textos, 2007.

TEIXEIRA, W. Vulcanismo: produtos e importância para a vida. In: TEIXEIRA, W (et. al) (org). Decifrando a terra. p: 348-380. São Paulo, Oficina de Textos, 2007.

THOMAZ-FILHO, A. et. al. Rifting And Magmatism Associated With The South America And Africa Break Up. Revista Brasileira de Geociências, 30 (1) p: 17-19, 2000.

VANDOROS.P; OLIVEIRA, M.A.F. Sobre o Fonólito de Mecejana, Ceará. Anais da Academia Brasileira de Ciências p: 40-42, 1968.

WINGE, M (org.). Dicionário geológico ilustrado. CPRM, 2014. http://sigep.cprm.gov.br/glossario/index.html. Acessado 11 de novembro de 2018 ZANElla, M. E. As Características Climáticas e os recursos Hídricos do Estado do Ceará. Ceará: Um Novo Olhar Geográfico. Org: DA SILVA, J.B. et. al. Fortaleza, Ed: Edições Demócrito Rocha, 2005. 